Göteborg Papers in Economic History

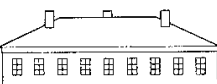
丒男男田田田思田

No. 6. December 2006

ISSN: $1653-1000$

The income distributional consequences of agrarian tariffs in Sweden on the eve of World War I

Jan Bohlin

Department of

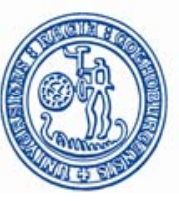

School of Business, Economics and Law GÖTEBORG UNIVERSITY 


\title{
The income distributional consequences of agrarian tariffs in Sweden on the eve of World War I*
}

\section{Jan Bohlin}

\author{
Jan.Bohlin@econhist.gu.se
}

\begin{abstract}
After 1870 Swedish agriculture was transformed in the direction of more animal husbandry. Small farmers in particular specialized in animal produce. Yet, agricultural protectionism primarily served the interest of large landowners specializing in bread-grain production. The paper explores the impact of agrarian tariffs on the factor rewards of landowners, capitalists and workers. Landowners predictably benefited from agrarian tariffs, the more so if they specialized in bread-grain, as did rural workers. With an integrated ruralurban labour market real incomes of urban workers would have come under pressure if agrarian tariffs had been dismantled while capitalists would have been little affected.
\end{abstract}

JEL: F13, C68, D33, N23, N33, N43

Keywords: Economic History, Protectionism, Trade Policy, Income Distribution, Computable General Equilibrium Model

ISSN: 1653-1000 online version

ISSN: $1653-1019$ print version

(C) The Author

Göteborg University

School of Economics and Commercial Law

Department of Economic History

P.O. Box 720

SE-405 30 GÖTEBORG

www.econhist.gu.se

* The research for this paper has been supported by grants from Jan Wallanders and Tom Hedelius Stiftelse and the Bank of Sweden Tercentenary Foundation. I also would like to thank Svante Larsson for helpful comments. 


\section{Introduction}

Falling international grain prices and increasing imports of grain into Western Europe in the 1870's and 1880's caused falling profitability for grain producers and falling land prices in West European countries. The grain invasion provoked different responses in different countries. While some countries, notably Denmark and the UK, stuck to free trade in agricultural commodities, others such as France, Germany and Sweden imposed tariffs to protect landowners.

According to Kevin O'Rourke the varying responses to the grain invasion depended on its impact on land rents and the role of agriculture in national economic life. ${ }^{1}$ In the UK the weight of the agricultural sector in the national economy was already much reduced and in Denmark farmers were already well on their way in switching over to animal produce. In contrast, on the European continent cereal production was much more important. The response to the grain invasion probably also had something to do with the political clout of landowners. In a classical study Alexander Gerschenkron argued that in Germany agrarian protectionism only benefited a minority of relatively large landowners specializing in bread-grain production. ${ }^{2}$ According to Gerschenkron, small farmers did not gain much from agricultural protection even though they produced grain, since they used their grain produce primarily for own consumption and fodder. Against Gerschenkron, Steven Webb has argued that the output mix did not differ much between small farms and large farms and that animal produce also received substantial tariff protection in Germany. ${ }^{3}$

In Sweden as in Germany, the campaign for grain tariffs was primarily conducted by large landowners, specializing in bread-grain production. The majority of small farmers typically specialized in animal husbandry, which was much less exposed to overseas competition. Agrarian protectionism was filled with controversy from the beginning. In the debates on trade policy in the 1880's critics pointed out that grain tariffs primarily served the interests of large landowners in southern and mid-eastern Sweden, specializing in producing bread-grain. In answer, to win over the majority of small farmers, the protectionists also campaigned for the introduction of tariffs on maize and pork. Maize was considered a substitute for oats in the feeding of pigs and adherents of protectionism argued that the maize tariff would primarily benefit small farmers since oats was their most important crop. However, as free traders pointed out, pig farming was also more important for small and middle-sized farms than for large farms, and the feeding of pigs was made more expensive by the maize tariff. Moreover, the most important source of revenue for small farmers derived from milk production which was unprotected. ${ }^{4}$

After the intense debates over tariffs in the 1880's the controversy faded during the general economic upswing in the 1890's, when the protectionist system had been settled. A new controversy over food

\footnotetext{
1 O’Rourke, ”European Grain Invasion”.

2 Gerschenkron, Bread and Democracy.

3 Webb, "Agricultural Protection".

4 Gellerman, Staten och jordbruket, pp. 17-43.
} 
tariffs was again brought to the fore around 1910.5 Many male workers now had a yearly income exceeding $800 \mathrm{kr}$ and had thereby gained the right to vote in parliamentary elections. Accordingly, the Social Democrats could now muster a sizable representation in the parliament. Increasing unemployment in the wake of the economic crises in 1907 resulted in hardships for many workers. Food tariffs, in particular grain tariffs, were now singled out for critique by the Social Democrats in alliance with the so called Norrland liberals, representing small farmers from northern Sweden, where grain production had always been of marginal importance. However, the critique of grain tariffs proved to be half-hearted since the Social Democrats feared that abolishing agricultural tariffs would lead to demands from farmers for the dismantling of tariffs also on industrial products. The Social Democrats feared that many industries were dependent on tariffs, and that their withdrawals would lead to increased unemployment. In addition, grain tariffs were now an important source of revenue for the government and it was believed that their withdrawal would lead to a fiscal crisis. This would in turn have necessitated compensatory increases in other taxes. Another consideration was that Social Democrats were divided on the issue. Many small farmers had now joined the party and they were generally for agrarian protectionism.

The only practical result of the controversy over agrarian tariffs was that the maize tariff was abolished in 1911. Critics of food tariffs were hampered by lack of factual knowledge ${ }^{6}$ of conditions in agriculture and the probable impact of a dismantling of agrarian tariffs on different farmers. Data collected in the 1910's and the early 1920's has improved our knowledge of the output mix of farms of different sizes, which makes it possible to answer some of the issues at stake in the contemporary debates on food tariffs before world War I.

Since animal products were substantially less protected than bread-grain an intriguing question is whether agrarian protectionism in Sweden benefited only a minority of relatively large landowners specializing in bread-grain production, as Gerschenkron claimed was the case for Germany in the same period. The purpose of this paper is to explore the income distributional consequences of agrarian tariffs in Sweden before World War I. Did they benefit only a minority of relatively large landowners specializing in bread-grain production, or did the majority of small farmers also profit from them, and how did they affect real wages of urban workers and the rate of return on capital in the manufacturing industry? In the next section I outline some of the main features of agricultural development in Sweden in the late nineteenth and early twentieth centuries. Thereafter, I show how arable and animal produce was distributed between farms of different sizes on the eve of World War I, and I also present data on the varying extent to which these farms benefited from agrarian protectionism. In the final section of the paper I explore the impact of agrarian tariffs by means of a Computable General Equilibrium model, calibrated with data from 1913.

Ibid., pp. 191-212.

6 The Social Democrats demanded that a public investigation committee was set up to explore the effects of tariffs, ibid., pp. 202-203. In addition, an internal party committee had been appointed to improve factual knowledge on the issue and draw up the party's policy. Nothing seems to have come out of it, Gellerman, Staten och jordbruket, pp. 191-192. 


\section{Swedish agriculture in 1870-1913, bread-grain protection and increasing specialization in animal produce}

The perhaps most visible sign that the world economy had entered an era of globalization in the late nineteenth century was the emergence of an international grain market that determined grain prices in each corner of the world. Falling transport costs and free trade led to sharply falling grain prices from the middle of the 1870 's. In Sweden, as in other countries on the European continent, this led to falling profitability for farmers and a drop in land prices.

To stem the competition from overseas grain, landowners campaigned for the reintroduction of grain tariffs. In 1888 the protectionists won the majority in the Swedish parliament and tariffs on bread-grain and flour were introduced as well as tariffs on animal food products. ${ }^{7}$ The tariff on barley, rye and wheat was set to $2.5 \mathrm{kr}$ per 100 kilo, while oats was protected by $1 \mathrm{kr}$ per 100 kilo. When international grain prices rose in the beginning of the 1890's, tariffs on barley, rye and wheat were lowered to $1.25 \mathrm{kr}$ per kilo in 1892, while the tariff on oats was abolished. Thereafter world market prices fell again. To protect Swedish producers the tariff on barley, rye and wheat was raised to $3.70 \mathrm{kr}$ in 1896 , and stayed unchanged thereafter. For barley and rye, the specific tariff on bread-grain translated into an ad valorem protection of 30-35 percent for most years, while the protection for wheat was somewhat lower due to its higher price. Tariffs on flour were introduced concomitantly with grain tariffs. In 1888, a tariff of $4.30 \mathrm{kr}$ per 100 kilo was imposed on flour. It was lowered to $2.50 \mathrm{kr}$ per 100 kilo in 1892 and raised to $6.50 \mathrm{kr}$ per kilo in 1896 , which amounted to an ad valorem tariff of $40-45$ percent for most years.

The impact of the bread-grain tariff on Swedish grain prices can be seen from Figure 1 and Figure 2, showing the evolution of world market prices and domestic prices for rye and wheat, and the extent to which the tariff drove a wedge between world market prices and domestic prices. Swedish producers more or less entirely utilized the tariff on wheat (Figure 2), whilst for rye the price gap between Swedish and world market prices did not make up the whole tariff (Figure 1). Especially when world market prices rose, as they did between 1905 and 1910, the gap between Swedish and world market prices in rye diminished.

The grain tariff thus succeeded in at least partially insulating Swedish grain prices from world market prices. After 1888, export of Swedish bread-grain virtually ended, since producers profited more by selling in the protected home market. For rye, the grain tariff also led to a decline in the share of imports in the home market. The import penetration ratio in rye declined from over 20 percent in the early 1880's to 12 percent in 1911/13 (Table 1). Demand for wheat was more income elastic than for rye, but Swedish climate and soil quality was generally less suited for growing wheat. Only on the plains of Scania and mideastern Sweden were it profitable to grow wheat to any extent, despite the fact that tariffs made it possible for Swedish wheat producers to obtain prices which were 25-30 percent above world market prices. Consequently, the import penetration ratio in wheat increased from 30-35 percent in the 1880's to about

\footnotetext{
7 Bohlin, "Tariff Protection".
} 
60 percent around the turn of the century. Thereafter, Swedish producers were able to increase their market share to about 50 percent of the domestic market on the eve of WW I (Table 1).

Animal produce also received protection. Tariffs on livestock were low and quite inconsequential, however, since transport costs and quarantine rules made for low trade volumes anyhow. More important was the tariff on pork of $0.20 \mathrm{kr}$ per kilo, amounting to an ad valorem tariff of about 20 percent. The most important animal product, milk, was free of duty. It may be argued that milk producers enjoyed protection since the dairies, a major market for milk producers, were protected by a specific tariff on butter and margarine of $0.20 \mathrm{kr}$ per kilo, translating into an ad valorem tariff protection of about 15 percent for dairy products. ${ }^{8}$ However the butter tariff was largely inconsequential, since the Swedish butter price was more or less the same as the world market price ${ }^{9}$ as may be seen from Figure 3 where prices on Swedish and Danish butter of similar quality are compared. ${ }^{10}$

Bread-grain tariffs may have caused an increase in cereal acreage in Sweden, in contrast to Britain and Denmark, who adhered to free trade. ${ }^{11}$ That tariffs influenced farmers' choice of output mix can be seen clearly if we compare regions in Scania in southern Sweden with regions in neighbouring Denmark with similar climate and soil quality. In Scania, wheat growing expanded after the imposition of grain tariffs while it declined in the Danish regions. By contrast, fodder grain output and animal produce increased more in the Danish regions than in Scania. ${ }^{12}$ However, the most salient feature of Swedish land use in the late nineteenth century is not that the area devoted to bread grain production increased, but the much stronger increase in cultivated land used for growing fodder grains and green fodder of various sorts. Reclaimed land and land converted from meadows to arable was primarily used to produce fodder for the animals. These tendencies are clearly visible from Table 2 . The bread-grain acreage increased by 11 percent between 1880 and 1910. At the same time, the acreage devoted to the growing of oats, which was primarily used as fodder, increased by 28 percent, and the fodder grain acreage increased by 62 percent. The area occupied by meadows declined by 33 percent between 1880 and $1910 .{ }^{13}$

To sum up, the percentage of the total cultivated acreage devoted to animal fodder increased from 53 to 64 percent between 1885 and 1913, while at the same time the bread-grain acreage declined from 15.3 to 13.7 percent. Swedish agricultural statistics on cultivated land has been accused of overstating the increase in the cultivated acreage in the late nineteenth century. ${ }^{14}$ However, in 1910 and probably also in the 1890's it should be fairly accurate. It is also agreed that the percentage distribution of land between different crops is more accurate than the estimate of the total cultivated acreage. The trend in land use is anyhow unmistakable, and corrected numbers of the cultivated area would most likely show an even slower growth in the area devoted to bread-grain.

8 Ibid.

9 Jörberg, History of Prices in Sweden, II, p. 211.

10 Denmark was the leading exporter of butter at the time; see Henriksen and O'Rourke, "Incentives, Technology".

11 O’Rourke, "European Grain Invasion", table 4.

12 Höijer, Jämförelse.

13 Höijer, Tabeller.

14 Holgersson, "Cultivated Land in Sweden". 
The change in the distribution of land use towards more fodder grains must bee seen against the background of an ongoing transformation of Swedish agriculture in the direction of more animal produce. While the volume of arable produce stagnated or even declined after 1870, the volume of animal produce increased by 2.3 percent per year between 1870 and 1913, as is visible from Figure 4. Prices for animal products did not nearly decline as much as did arable products from the 1870's to the 1890's (Figure 5). When prices on arable products increased in the 1890's the prices of animal produce followed suit. Of even more importance than prices for the increasing specialization in animal produce was the fact that the income elasticity of demand for animal products was much higher than for arable products. In addition, milk, the major product of Swedish animal husbandry, also benefited from increased export demand, since it was indirectly exported in the form of butter. Butter was a major export article at the time. ${ }^{15}$ Its share of total Swedish exports was 10-13 percent at its height in the 1890's, but after the turn of the century butter exports stagnated and its relative share of Swedish exports sank to about 5-7 percent. ${ }^{16}$

\section{Output mix and effective protection for farms of different sizes}

\subsection{Distribution of land and output mix among farms of different sizes}

Data collected in the 1910's and the early 1920's have improved our knowledge of the output mix of farms of different sizes, which makes it possible to answer some of the issues at stake in the contemporary debates on food tariffs before world War I. From a special investigation from 1919 we have information on the distribution of cultivated land on farms of different sizes, measured by cultivated acreage. We also have information on the number of animals of various sorts on these farms. From these data it is possible to obtain estimates of the output of arable and animal products on farms of different sizes in $1913 .{ }^{17}$

Table 3 reveals that the distribution of land among farms was unequal. The majority of farms cultivated an acreage that was smaller than five hectares. Of all farms 77 percent were smaller than ten hectares. They cultivated about one third of the total acreage. Measured in cultivated acreage, only 2 percent of the farms were larger than 50 hectares, but they cultivated about 20 percent of the total acreage.

The output mix of arable and animal products of various sorts among farms of different sizes is shown in Table 4. Small farms (up to ten hectares) were clearly specialized in animal produce. Arable output on these farms was largely complementary to animal output, since it consisted predominantly of oats which was mainly used to feed the animals. Production of bread-grain was of marginal importance on small farms. In contrast, for the larger farms cultivating land of more than 30 hectares, bread-grain production was of much larger importance. If we disregard oats, bread-grain accounted for about 40 percent of total output on farms with an acreage of over 30 hectares.

The different roles of arable and animal products on farms of varying sizes also emerge clearly from Table 5, showing how much of total output of various products that was supplied by farms of different sizes. Production of bread-grain was largely concentrated to large farms. Small farms (below ten hectares),

15 Staffansson, Svensket smör, p. $99 \mathrm{ff}$.

16 My own estimates from Swedish foreign trade statistics.

17 For an account of sources and estimation techniques, see Appendix 1. 
on the other hand, accounted for a sizable share, almost 50 percent, of milk output. In contrast, of total bread-grain output small farms produced less than a third. If we consider only wheat farming, small farms were of even less importance; of total wheat output they only produced about 10 percent.

The much more important role for bread-grain production on large farms is also confirmed by Ernst Höijer in a report commissioned by the public investigation committee on the tariff system, appointed after World War I. ${ }^{18}$ Höijer explored to what extent farms of different sizes were able to produce enough bread-grain to provide for the consumption by family members and hired farm-hands between 1913 and 1919. He calculated that people occupied at farms of sizes up to 5 hectares were dependent on purchasing bread-grain to cover their deficits, while farms of sizes between 5 and 10 hectares barely covered their consumption from their own production. Only large farms, of sizes over 30 hectares, produced sizable marketable surpluses of bread-grain. According to Höijer's estimate, more than half of the countryside population was dependent on purchase from larger farms for their consumption of bread-grain.

\subsection{Effective protection for farms of different sizes}

We have seen that the rate of protection varied considerably between different agricultural products. Since farms of different sizes specialized in different kinds of products they did not benefit to the same degree from the protectionist system. Of concern for the farmers was not only the tariff protection they received on their own produce but also to what extent their costs increased because of tariffs that they might have to pay on purchased inputs. If tariffs increased their revenues by a higher percentage than their purchased inputs they gained from the protectionist system. The rate of effective protection gauges by how much value added increases compared to a hypothetical situation of free trade. ${ }^{19}$ In calculating effective protection rates I have assumed that fertilizers were the only purchased inputs in arable production and concentrated fodder of various sorts, such as oats and oil-seed cakes, were the only purchased inputs in animal production. My estimates of nominal and effective tariff protection for various agricultural products are displayed in Table 6 and Table 7.

Since the share of costs for purchased fertilizers in the sales value of grains only amounted to 5-10 percent and the tariff rate on fertilizer was quite low (4-5 percent) the difference between the nominal and the effective protection rate was not large for grains. In animal produce it was only the production of hogs that was protected to a substantial extent, but the maize tariff also made the feeding of hogs more expensive. In 1901/06 the maize tariff of $1.25 \mathrm{kr}$ per 100 kilo amounted to an ad valorem tariff of 11-13 percent. When in 1906 the tariff on maize, the prize of which had declined relatively to oats, was raised to $3.7 \mathrm{kr}$ per 100 kilo the effective protection of hogs production was sharply reduced and hogs output fell, leading to increased import penetration of pork. In 1908 the maize tariff was reduced to $1.5 \mathrm{kr}$ per 100 kilo, after which it was abolished in 1911. The dismantling of the maize tariff in 1911 stimulated Swedish

18 Höijer, Utredning.

19 See for example Corden, Theory of Protection. 
pig farming. Import penetration of pork fell and Swedish producers captured a larger share of the home market.

To sum up, Table 7 shows clearly that with the notable exception of pig farming animal produce was considerably less protected than arable produce. By putting together information gathered in Table 6 , Table 7, and Table 5 we may calculate the rate of protection for farms in different size classes in 1911/14. The results from such a calculation are displayed in Table $8 .{ }^{20}$

Since in Sweden the share of unprotected goods, such as oats and milk, was much more important in the output mix of small farms than of large farms we may conclude that the majority of small farmers benefited to a much smaller degree than large farmers from agricultural protectionism. The data presented so far explain why owners of large estates were the most ardent supporters of agrarian protectionism. Large landowners also succeeded in rallying support for tariffs from small farmers, as owners of small farms would also lose revenues from a withdrawal of tariffs, although not to the same extent as large farmers. However, counterfactual speculations of this sort do not take into account that the level of output and the output mix would hardly have stayed unchanged after a tariff reform. As a result of tariff changes prices would have changed, not only agricultural and food prices but all prices, not the least factor prices. Changes in relative prices would in their turn have affected resource allocation, which would have affected product prices and so forth. These issues will be explored in a general equilibrium framework in the following sections.

\section{A Computable General Equilibrium model of the Swedish economy in 1913}

The general idea behind a Computable Equilibrium Model (CGE model) is the interdependence of an economic system. Changes in one market will have repercussions on all markets. It is assumed that every market clears. The economy is supposed to be populated by rational agents that maximize or minimize objective functions subject to restraints. Consumers maximize utility functions subject to the restraints of their income while entrepreneurs minimize cost functions subject to the technology and inputs at their disposal.

A CGE model has four types of exogenous variables: endowments, technology, consumer preferences, and policy variables such as taxes of various sorts. An economy's factor endowments and technology determine its production possibility frontier. The technology of a sector, expressed by a production function, specifies how inputs may be combined to produce output. Cost functions derived from production functions generate demand functions for the factors. Factors are owned by agents who receive income from their ownership. These incomes are used to buy goods. In choosing between goods, consumers are guided by their preferences. Consumer preferences are modelled by utility functions which

20 Apparently, the effective protection for agriculture in Sweden was much lower than in Germany at the same time. This is primarily explained by the fact that in contrast to Germany oats and milk were not protected in Sweden. This also explains another contrast between Sweden and Germany, namely that in Sweden small farms received much less benefits from agricultural protectionism than large farms did while in Germany the gains from protection were quite equally spread among farms according to Webb. See Webb, "Agricultural Protection", table 4. 
specify how consumers combine inputs of various commodities, subject to the restraint of their incomes, to "produce" utility. From these utility functions final demand functions for the various good are derived.

To be usable for analyzing real problems the abstract CGE model must be calibrated with data for a real economy in a benchmark year, in which the economy is assumed to be in a state of general equilibrium. For example, in order to explore the consequences of a particular trade policy reform the model economy is shocked by altering tariff rates. To find a new general equilibrium the economy will then have to adjust by altering relative prices. As a consequence factors of production will be reshuffled between the sectors and output levels of the various sectors will change.

It is important to realize the limitations of this type of analysis. In a CGE model relative price changes bring forth a new equilibrium and a reshuffling of factors of production among sectors. Arguably, the possibility to reallocate factors of production is limited in the short run. Once installed in an industry a given piece of capital equipment is specific for that line of activity and can hardly move to another industry. Moreover, the economy is not simply "endowed" with capital and labour. Capital is accumulated and labour migrates in response to perceived economic opportunities. More important than a reallocation of existing resources at a point in time is how the present, for example a "shock" such as a tariff reform package, influences capitalists decisions to invest or disinvest and workers decisions to migrate or not, and thereby also the long-run evolution of "factor endowments".

A way to accommodate such long-run effects is to simulate a sequence of equilibria through time. In the period between the different equilibria endowments and possibly other exogenous variables are updated and then a new general equilibrium is solved and so on. ${ }^{21}$ However, more common seems to be to use CGE models in comparative static explorations. The idea is that by endowing the economy with more or less of a factor or by changing policy variables such as taxes, while leaving everything else the same, it is possible to counterfactually sort out the importance of the particular factor or tax rate. In these counterfactual scenarios it is typically assumed that "capital" is malleable, that it can be reshuffled between the sectors, or else it is equally strongly assumed that had the economy developed under different factor endowments or taxes the composition of physical capital might have been different than in the actual economy and fully appropriate to the structure of demand in the counterfactual economy, while everything else remains the same. ${ }^{22}$

\subsection{Description of the model}

The empirical backbone of the model is a Social Accounting Matrix (SAM) of the Swedish economy in 1913, exhibited in Appendix 2 (Table 1, Table 2 and Table 6). The model has been constructed primarily to analyze trade policy issues. For this purpose I have divided the economy between the following sectors: Export industry (EXP_IND) ${ }^{23}$, Capital goods industry (CAP_IND), Consumer goods industry

21 See for example the classic work by Adelman and Robinson, Income distribution policy.

22 See for example O’Rourke and Williamson, "Open Economy Forces".

23 In this sector the classical Swedish export industries are included: Iron Ore Mines, Saw Mills, the Paper industry, Pulp mills, and also the Stone quarrying industry. These industries were generally unprotected. The paper industry 
(CONS_IND), Forestry (FORESTRY), Building and construction (CONSTRUCT), Private services (including housing, and transports and communications) (SERVICES), Public services (PUBLICSERV). To explore the impact of agrarian tariffs I have subdivided the agricultural sector into three sectors: a bread-grain sector (AGRI_BREAD) 24 , a sector producing other arable products (AGRI_VEGE) and a sector producing animal products (AGRI_ANIM) ${ }^{25}$. For the same purpose I have also subdivided the food industry into two sectors: a sector producing animal food products (FOOD_ANIM) ${ }^{26}$ and another sector using bread-grain, vegetables and other arable products as inputs (FOOD_VEGE). In addition, two sectors of non-competitive imports have been included in the model to account for goods consumed but not produced in Sweden, namely non-competing capital goods and raw materials (RAWMAT) ${ }^{27}$, and non-competing agricultural goods (NC_AGRIC) ${ }^{28}$.

Each sector uses intermediate goods in fixed proportions to value added, that is the elasticity of substitution between intermediate goods and the value added aggregate is zero (the Leontieff technology assumption). Capital and labour in combination produces value added. As is customary in CGE models, it is assumed that the "technology" can be described by a Constant Elasticity of Substitution (CES) production function. Once an investment has been made and a capital good is put into place it is considered specific for that sector. In other words, the rate of return on "capital" varies between sectors.

In the literature on CGE models it is common to distinguish between land and capital as two separate factors. ${ }^{29}$ Thus, it is often claimed that agriculture produces its output using land, labor and capital in cooperation. I do not follow this practice. In my model there is no separate factor land apart from capital in the agricultural sectors and for clarity it is worthwhile to make a digression to explain why. The distinction between the three factors land, labour and capital has its root in classical economics. The ground for making a separation between land and capital is that capital is a produced factor, a result of a previous history of accumulation, while land is given by Mother Nature. Land is therefore "scarce" in an absolute sense and cannot be augmented by accumulation. The scarcity of land also gives rise to rent as a separate economic category. The classical theory of land rent is at heart a theory of differential rent. A piece of land of superior quality yields higher output than land of lower quality of the same size, because it is unique. It therefore also yields higher rent or can be sold at a higher price than a piece of land of inferior quality. If all land were of the same quality there would be no basis for rent as a separate

was protected, but since it was a major export industry, tariffs were inconsequential for a large part of this industry.

24 Barley, rye, wheat, sugar beets, beans, peas and horticultural products.

25 This sector also includes fisheries.

26 This sector includes Slaughter Houses and Dairies.

27 Here I include products such as coal, coke based pig iron and other bulky steel products, which were hardly produced in Sweden, certain chemical raw materials but also consumer goods raw materials such as fur and hides, cotton, wool. The distinction between what should be counted as non-competitive and competitive is to a certain extent arbitrary. For example Sweden did produce wool and hides, but Swedish producers were fairly marginal as suppliers of these raw materials. All products in this sector were free from tariffs.

28 The most important non-competing agricultural goods were coffee beans and tobacco. Other products were for example citrus fruits. Fiscal tariffs were imposed on products in this sector. Again, the distinction between what should be counted as non-competitive imports and as competitive imports is not clear-cut. For example, Sweden did produce raw tobacco in greenhouses.

29 See for example, O’Rourke, ’European Grain Invasion". 
economic category. In addition, land is not simply given by nature. The value of land cannot be separated from the investments that have been made to make it usable, in land clearance, ditching etc. For the farmer the distinction between land and capital is uninteresting. He bought or inherited his farm in one piece. He does not know and does not care if his revenues emanate from his farm buildings, his equipment or his soil. The one is useless without the other in the same sense that a factory building is useless without the machines installed in it. What interests the farmer, however, is if his land yields more or less than other land worked with the same effort and equipment, but then we are back to the concept of differential rent. Since there is no differential rent in the model there is no place for "land" as a separate "factor" besides "capital" in the agricultural sectors.

It can be shown that wage rates for labour of the same kind differ persistently between sectors. These differences may be caused by skill differences and institutional factors such as varying bargaining powers of capital and labour. To model the persistence of such "wage distortions" I have assumed that relative wages between sectors do not change for labour of the same kind. Shifts in the demand and supply curves affect the price of labour, but the wage structure for labour of the same kind stays intact. ${ }^{30}$

Three sectors produced only for the home market and were insulated from competition by imports: the building and construction sector, the private services plus transport sector ${ }^{31}$, and the public services sector. Other sectors faced competition from the world market. I have assumed that Sweden was a "small country" as far as her imports were concerned. Accordingly, if domestically produced and imported goods were exactly alike, Swedish prices for goods facing import competition would be equal to world market prices plus the tariff rate. In that case the home market would be completely dominated by either homeproduced goods, if the tariff rate was high enough, or by imports. Economic statistics show that this does not happen; countries export and import the same types of goods. Arguably the statistics are too aggregated, but even with quite disaggregated statistics it has been shown that the phenomenon of "crosshauling" does not disappear. Therefore, in CGE modelling it is customary to apply the so called Armington assumption, according to which domestically produced goods and imported goods in a sector are separate goods that may be substituted for each other. The degree to which a price change calls forth a substitution between domestically produced goods and imported goods is determined by an elasticity of substitution.

Industrial and agricultural goods were not sold directly to the final consumer. They were processed by the retail trade sector before final consumption. In line with Swedish Historical National Accounts ${ }^{32}$ I

30 This modelling device was introduced by Leif Johansen in his seminal Norway model, see Johansen, Multi-Sectoral Study. It has since been used in many applications. See for example Karlström, Economic Growth and Migration, Vikström, Big Picture.

31 The private services and transport sector generated export incomes, but these resulted from commercial margins on commodity exports from other sectors and from shipping the export goods to foreign ports. The export income emanating from the services and transport sector should be viewed as an input to final exports. I have assumed that exports from other sectors are marked up by 26 percent by the SERVICES sector to arrive at final export values. This percentage corresponds quite well to the share of total export incomes generated by private services and transports according to Swedish Historical National Accounts.

32 Krantz, Historiska nationalräkenskaper för Sverige: Privata tjänster. 
have assumed that those goods were marked up by the SERVICES sector by a given percentage on the sales value. ${ }^{33}$

While it seems pertinent to regard Sweden as a price taker regarding her imports, the "small country" assumption is hardly fitting for Swedish exports. Sweden was a major exporter in for example iron ore, sawn timber, pulp and paper, so we cannot assume that Swedish exporters faced infinitely elastic demand curves for their exports. In each sector foreign demand for Swedish exports are expressed by export demand functions with sector specific export demand elasticities. It is assumed that the exporting sectors decided on whether to supply their products to the home market or to the export markets on the basis of relative prices in the two markets. A common device in CGE modelling, which is used also in this paper, is to assume that home market goods and export goods in a sector could be transformed to each other via a constant elasticity of transformation (CET) function.

Exports generate foreign exchange which is used to buy imports. If export incomes fall short of the value of imports there is an inflow of foreign savings. Capital inflow was an important feature of Swedish economic development from the 1870's to World War I. ${ }^{34}$ Furthermore, the debts contracted in these decades resulted in contractual interest payments on the loans and accordingly an additional outflow of foreign exchange. ${ }^{35}$ It was only in the years immediately preceding World War I that the Swedish trade balance started to turn positive. Also important was that Swedish emigrants to the United States sent money home to their relatives. This inflow of foreign exchange was of some importance at the time and it is included in the calculation of foreign savings in the benchmark. ${ }^{36}$

There are three income recipients in the model: a representative consumer, the government, and a fictitious agent called the investor. The representative consumer receives income in the form of factor rewards, net of income taxes. Part of the income is saved. It is assumed that a constant fraction of incomes is saved by the consumer. The remaining disposable income is used to buy goods. When income changes, it is highly unlikely that the pattern of consumption stays unchanged. In other words, the income elasticity of demand differs between various types of good. To allow for such effects I have modelled consumption by means of the Stone-Geary Linear Expenditure System (LES). ${ }^{37}$ In the LES, the consumption of a good consists of two parts. One part, which may be labelled the subsistence level of expenditure, stays the same irrespective of what happens to prices and/or income. The other part is proportional to the income that remains after the subsistence quantities have been bought and may also be viewed as the marginal propensity to consume a good. These marginal shares stay the same as income

33 I have assumed a margin of transport and trade services of 30.8 percent on final consumption goods in line with figures in the Historical National Accounts.

34 Schön, "Kapitalimport, kreditmarknad och industrialisering".

35 I have assumed that the rate of interest on the stock of foreign debt was 3 percent which was paid on a foreign debt of $2660 \mathrm{~m} \mathrm{kr}$ in 1913. This results in a "negative endowment" of foreign exchange in the benchmark amounting to $79.8 \mathrm{~m} . \mathrm{kr}$.

36 In 1913 emigrant remittances resulted in an inflow of $36 \mathrm{~m}$. kr of foreign exchange. See Lindahl, Dahlgren, and Kock, National Income, Part Two, pp. 598-99, table 174.

37 Stone, "Linear expenditure systems". 
rise, so the LES may also be viewed as a Cobb-Douglas utility function displaced from the origin. ${ }^{38}$ In the model there is only one representative consumer, that is capitalists, workers and farmers are assumed to consume and save in exactly the same manner. That is obviously a gross oversimplification. If data had permitted it would have been preferable to have several separate income recipients, each with separate utility functions.

The government receives income by collecting taxes ${ }^{39}$ and uses this income to demand the output of the public services sector. The government is the only consumer of the output of the public services sector (PUBLICSERV). The public services sector purchases few inputs from other sectors so the sales value of public sector output does not change much in the various simulations; it would only change as a result of changing wages for public sector employees. If the government's income is larger than its outlay, which was the case in 1913 according to the benchmark SAM, the difference is saved. I have assumed that the level of government expenditures is exogenously given.

Tariffs were an important source of revenue for the government. In 1913 tariffs accounted for 22 percent of total taxes. ${ }^{40}$ Of these grain and food tariffs (excluding so called fiscal tariffs) made up roughly 25 percent. ${ }^{41}$ Consequently, as a result of abolishing agricultural and food tariffs the government budget would turn from surplus to deficit. I assume as part of a tariff reform package that income taxes would rise endogenously to cover the eventual deficit resulting from diminishing tariff revenues.

The investor collects the savings of the representative consumer and the government. In addition, this agent also receives any capital inflow from the rest of the world and services foreign debt incurred in earlier periods. The investor uses the savings he commands over to demand investment goods. There are no inventories in the model and hence no inventory investments. It is assumed that the volume of investment in fixed capital (machinery, equipment and buildings) is fixed, conceivably because it was ordered in a previous period. Foreign savings adapt to ensure that total savings will always equal investments.

A CGE model solves for relative prices, one commodity must be assigned the role of a numeraire. For this purpose I use the price of foreign exchange, the real exchange rate, which is set to unity. The model has been implemented and solved using the GAMS/MPSGE software.

\footnotetext{
38 The baseline consumption levels of the various goods in the model are given in Table 3 in Appendix 2.

39 The tax system at the time was a complicated mixture of taxes of various sorts. For simplicity I assume that all factor owners pay an income tax amounting to 4.7 percent of their income. This rate conforms fairly well to total state and municipal income taxes in 1913, see Gårestad, Industrialisering och beskattning, table 1. It would have been preferable to make a distinction between income taxes on wages and other factor incomes. The income tax rate for workers was lower than for other income categories and some workers with low income paid no income taxes at all. Another important source of revenues for the government was indirect taxes. Sales taxes were levied on liquor, sugar and beer, ibid., table 3. I assume that the FOOD_VEGE sector paid 5 percent of sales revenues in sales tax.

40 Ibid.

41 Calculations from foreign trade statistics.
} 


\section{What would have happened if agrarian tariffs had been removed? Counterfactual simulations}

\subsection{Preliminary remarks on data}

To better interpret the counterfactual scenarios reported in this section it is useful to first make a few remarks about the data and elasticities used in the model. The input-output table of the Swedish economy in 1913 (Appendix 2, Table 6) and the final demand table (Appendix 2, Table1) clearly shows that the main outlet for the products of the agricultural sector was the food industry; the AGRI_BREAD sector provided the FOOD_VEGE sector with inputs and the AGRI_ANIM sector supplied the FOOD_ANIM sector. The forward linkages from the agricultural sectors to other sectors were of little importance. As a consequence the other sectors would be little affected by a withdrawal of agrarian and food tariffs, except through changes in wages and labour availability. It should also be noted that the AGRI_VEGE sector is essentially an adjunct to the AGRI_ANIM sector. Most of its output was delivered to the AGRI_ANIM sector and the two sectors might as well have been aggregated to one sector.

A special problem in calibrating the model is the choice of elasticities. There is admittedly not much empirical basis for deciding on the various elasticities that are used in the model. There seems to be three approaches in the literature: own econometric estimates, use of estimates obtained from other studies, and more or less educated guess work.

There is a large econometric literature on CES production functions. However, it has been shown that estimates of substitution elasticities are much dependent on the chosen specification. ${ }^{42}$ Karl G. Jungenfelt estimated that the elasticity of substitution in Swedish manufacturing was 0.6, by running a time series regression on data for Swedish manufacturing in the period 1870-1950 with the natural logarithm of labour productivity as the dependent variable and the natural logarithm of real wages as the independent variable. ${ }^{43}$ If we replace the data that were available to Jungenfelt by Lennart Schön's more recent data on value added in Swedish manufacturing ${ }^{44}$ the estimated elasticity of substitution does not differ much from unity. Be that as it may, Jungenfelt's estimate seems to have been accepted in other CGE-models for Sweden ${ }^{45}$ and an elasticity of substitution of about $0.5-0.6$ for the manufacturing industry also appears to be standard in CGE modelling. ${ }^{46} \mathrm{I}$ have therefore decided on an elasticity of substitution of 0.5 in the CES production functions for all but the agricultural sectors where the elasticity is set to unity, the argument being that if there is any activity where substitution between the factors of production is feasible to any extent it is within agriculture.

There have also been many attempts to estimate Armington elasticities econometrically. A common specification seems to be to regress time series data on the natural logarithm of the ratio

\footnotetext{
42 Heathfield and Wibe, Introduction to Cost and Production Functions, ch. 9.

43 Jungenfelt, Löneandelen.

44 Schön, Historiska nationalräkenskaper för Sverige: Industri.

45 Karlström, Economic Growth and Migration, O’Rourke and Williamson, ”Open Economy Forces”, Vikström, Big Picture.

46 See for example Federico and O’Rourke, "Much ado about nothing".
} 
imports/domestic output for the home market against the natural logarithm of the ratio home price/import price. ${ }^{47} \mathrm{I}$ have tried out the specification on many sectors of the Swedish economy for the period 1885-1913. In the few cases where I get coefficients that at least bear a resemblance to statistical significance, I nevertheless find them unreliable for my purposes. It has been shown that such estimates are very sensitive to the frequency of the data; high frequency data generally yields lower estimates than low frequency data. Lacking good price data, it makes sense to simply calculate the percentage change in the ratio imports/domestic output for the home market between two points in time and divide it with the percentage change in $1+$ tariff rate in the same period. However, another problem for counterfactual analysis is that the effect of a given percentage change in the tariff rate is hardly symmetrical with respect to the direction of the change. To give an example, between the late 1880's and the First World War the import penetration ratio for bread-grain (rye and wheat) declined very little in Sweden, in response to the introduction of a tariff in the range of 25-35 percent. This would yield an elasticity of substitution not much above unity. However, it is reasonable to assume that the elasticity of the world supply curve facing Swedish grain consumers was much higher, so that the percentage change in the import penetration ratio would have been quite large as a result of a dismantling of bread-grain tariffs. With this argument, I have set the Armington elasticity to 10 for the bread-grain sector. It seems reasonable to assume that the Armington elasticity was lower for the food producing industry, since varying national tastes should have served to reduce the inflow of imported goods in response to a withdrawal of tariffs. I have therefore decided on an Armington elasticity of 5 in the FOOD_VEGE and the FOOD_ANIM sectors.

The empirical basis for deciding on export price elasticities and CET transformation elasticities is even weaker than is the case for Armington elasticities and CES substitution elasticities. It is reasonable to assume that export price elasticities are considerably higher for primary goods and agricultural goods than is the case for industrial goods. The manufacturing industry produced differentiated goods and price was not the only argument in the competition for market shares. Furthermore, many Swedish export industries, such as saw mills and paper mills, were involved in international cartel agreements and they were not free to steel market shares by lowering prices. It seems to be standard practice in CGE models to set high numbers on CET transformation elasticities. ${ }^{48} \mathrm{I}$ have followed this practice for agricultural goods.

In the following three counterfactual simulations we look at what happens in the model when we remove all agricultural tariffs and the tariffs protecting the food industries. The sales tax on the output value of the FOOD_VEGE sector is also removed, but tariffs on NC_AGRIC imports are kept.

\subsection{Simulation 1, sector specific capital in all sectors, separate urban and rural labour markets}

In this simulation land and farm capital is specific to each sector of agricultural produce, that is land used for growing bread-grain cannot be used for pasture or for growing other arable products. The results from this simulation are reported in table 9. The most obvious effect is that prices fall steeply for bread-grain

47 See for example Irwin, "Could the United States iron industry have survived free trade".

48 See for example Federico and O'Rourke, "Much ado about nothing". 
producers. Import prices are reduced bye the whole amount of the tariff, 20 percent, resulting in a rise of import volumes by almost 50 percent. According to the assumptions in this simulation, land used for growing bread-grain has no other uses. In addition full utilization of all factors is assumed. Bread-grain output contracts since labour inputs are reduced. The revenues of bread-grain producers fall by 30 percent, primarily as a result of falling bread-grain prices. As a result, the factor rewards for owners of bread-grain farms take a dive by more than 30 percent.

The labour released from the bread-grain sector is employed in other agricultural sectors, leading to a slight increase in their output, which is sold at somewhat reduced prices, but on the whole, the AGRI_VEGE and the AGRI_ANIM sectors are little affected.

The output of the animal food industry (FOOD_ANIM) increases slightly. The vegetable food industry (FOOD_VEGE), on the other hand, faces harder competition from imports. The import volume increases by 75 percent and sales prices in this sector fall by almost 15 percent, but the output volume remains quite unaffected.

Post-tax nominal wages for rural workers decline by 7.2 percent. Because of increased imports of bread-grain the demand curve for labour shifts inwards in the agricultural sectors. Since full employment of rural labour is assumed the labour supply curve is infinitely inelastic and the inward shift of the labour demand curve leads to a commensurate decline in nominal wages. In the urban sectors, post-tax wages decline by 0.6 percent. However, both rural and urban labour benefit from lower prices on consumer goods which fall by 3.5 percent. ${ }^{49}$ Hence post-tax real wages for rural workers fall by 3.8 percent while they rise for urban workers by 2.8 percent. To prevent the government budget from falling into deficit as a result of declining tariff revenues income taxes are raised by 1.1 percentage units. ${ }^{50}$

\subsection{Simulation 2, sector specific capital in urban sectors, common factor "land" in agrarian sectors, separate urban and rural labour markets}

In this simulation, the results of which are reported in table 10, I drop the assumption that land used for growing bread-grain is confined to producing these crops. Surely the owners of this land could convert their wheat-fields and rye fields to pasture or to the growing of oats. To increase their stock of animals would take time and incur investment costs, but with a leap of faith we might perhaps envisage that their farm capital could somehow be effortlessly remoulded (less wheat fields, more pasture and livestock). Or else we might make the equally strong assumption that had there been no previous history of agrarian protectionism the same amount of capital might have been invested in the farms, only its composition would have been different. Thus, in the simulation reported in this section I assume that "land" can be used equally well for producing milk as for producing wheat or other crops, so that in all agricultural

49 In this and the following simulations the consumer price index refers to the consumption basket of the representative consumer. Since the consumption basket changes slightly in the counterfactuals I have used a Fisher index to calculate the index number.

50 The tariff reform package makes the government surplus disappear; the compensatory income tax increase is just enough to balance the budget. As a consequence domestic savings decrease and the benchmark balance of payment surplus of 3 million $\mathrm{kr}$ is about halved. 
sectors the primary factors are land and labour. ${ }^{51}$ I keep the assumption that there are two labour markets: one for rural and one for urban workers.

We first look at what happens to gross output following a tariff reform. The most obvious change is that bread-grain output falls by 39 percent and prices by 10 percent. As a result sales revenues fall by more than 40 percent. It may seem odd that the prices obtained by domestic producers fall by only 10 percent when import prices fall by 20 percent. One explanation is of course that the goods produced by domestic producers were not identical to imported goods; for example, horticultural goods are included in breadgrain output. However, the main reason for why consumers, according to the simulation, would be prepared to pay a price premium on home produced bread-grain is that the elasticity of substitution between home produced and foreign bread-grain is not modelled as infinite but assumed to be 10 . In the real world it might have been higher. The reason behind the contraction in bread-grain output is of course increased competition from imports. According to the simulation the volume of bread-grain imports increases by 105 percent.

The output of the vegetable food industry does not change much but sales prices decline by almost 15 percent leading to a decline of sales revenues at approximately the same rate. Prices fall also in the animal food industry (by 10 percent) but output increases more (by 16.5 percent), leading to increased sales revenues.

Following the tariff withdrawal, imports of vegetable food products (VEGE_FOOD) increases by 76 percent. The percentage change in imports is large also in the other agricultural and food producing sectors. However, the initial import levels were quite low in these sectors (see Appendix 2, table 1), so a high percentage rate of change only generates small level changes.

Exports from the agricultural and food producing sectors are affected by a tariff reform, but among these sectors only the animal food industry (FOOD_ANIM) had any sizable export from the beginning. Thus the 29 percent increase in the export volume of the ANIM_FOOD sector generates more export income than the combined increase in exports of the other sectors.

Of particular importance is how a withdrawal of food tariffs would have affected factor prices. According to the simulation, bread-grain landowners, pressed by competition from imports, switch over to other crops (AGRI_VEGE) and to animal produce (AGRI_ANIM), which raises output in these sectors. In order for the increased output to be absorbed by the market, prices would have to fall at approximately the same rate, leaving nominal output only slightly changed. All in all, the rewards to landownership fall by 15.9 as a result of the tariff reform.

Rural wages net of income taxes ${ }^{52}$ decline by 10.8 percent while urban wages stay largely unaffected. Of interest for workers would have been not only how money wages developed. Above all, they would

\footnotetext{
51 I have also tried out a simulation where animal output is produced by land, labour and capital specific to this sector (animal stock and equipment). To calibrate the benchmark data, I apportioned farm profits in the animal producing sector between "land" and the animal stock under the assumption that those "factors" received the same rate of return per invested kr. The results of this simulation was very similar to the one reported in this section. The factor rewards paid to land owners fall by roughly the same percentage rate and the factor rewards for owning the animal stock stay unaffected.
} 
have been interested in what they could buy for their wages. The consumer price index declines by 4.6 percent, so that post-tax real wages in the urban sectors rise by 4.0 percent, while those of rural workers decline by 6.3 percent.

The factor rewards to owners of capital in non food producing urban sectors are little affected. The only partial exception to this is the export industry, since its most important input, emanating from the forestry sector, falls in price, because of the fall in rural wages. The reward to capital owners in the animal food industry rises by a staggering 40 percent while it declines slightly (by 5 percent) in the FOOD_VEGE sector. Value added shares were low in the food producing industries, particularly in the animal food industry, hence falling input prices weigh much heavier in their costs than the rise in urban wages.

\subsection{Simulation 3, sector specific capital in urban sectors, common factor "land" in agrarian sectors, one labour market}

In this simulation I release the assumption of separate labour markets for urban and rural workers and assume instead that labour could move freely between the urban and rural sectors. This is the only change compared to simulation 2. I still maintain the assumption that there were persistent wage differences between the various sectors caused by a "wage distortion" factor. The results of the simulation are reported in table 11.

When allowing for labour mobility between the urban and rural sectors, nominal post-tax wages fall by 6.3 percent following a withdrawal of agricultural and food tariffs. Rural workers moving to the urban sectors put a downward pressure on wages and the income tax rate increases from 4.7 percent to 5.6 percent to compensate for falling tariff revenues. In this simulation workers are not fully compensated by falling consumer prices. The consumer price index falls by 4.9 percent, lowering real post-tax wages by 1.4 percent. Otherwise there is little difference between this and the previous simulation.

\section{Conclusions}

The invasion of cheap overseas grain in the 1880's provoked the reintroduction of grain tariffs in Sweden as in many other countries on the European continent. Agrarian protectionism was filled with controversy from the beginning. Tariffs were high on bread-grain, while protection of animal product was low and largely inconsequential in a period when the majority of Swedish farmers changed their output mix towards more animal produce. In the paper the income distributional consequences of agrarian tariffs on the eve of World War I are explored by means of a Computable General Equilibrium model of the Swedish economy, calibrated with data from 1913. Counterfactual simulations with the model make possible a few general conclusions.

Money wages of rural workers would generally fall as a result of removing agrarian tariffs. What would have happened to urban workers depends on the extent to which the rural and urban labour markets were integrated. If the two labour markets were insulated from each other, money wages of urban workers

\footnotetext{
52 The income tax rate increases by 1.2 percentage units, from 4.7 percent to 5.9 percent.
} 
would be little affected and they would enjoy increasing real wages because of falling food prices. If the urban and rural labour market were integrated into one labour market, money wages would fall also for urban workers. In this simulation competition from rural workers migrating to the urban centra would put downward pressure on post-tax money wages to an extent that would not be fully compensated by falling consumer prices. Accordingly, real wages would slightly decline. Important for this result is also that the income tax would increase to compensate for falling tariff revenues. While the exact results of this simulation are obviously open to dispute they make clear that workers would not unequivocally gain from a withdrawal of agrarian and food tariffs. It seems reasonable to assume that there was no Chinese wall between the urban and the rural labour market. After all rural-urban migration were prevalent in the decades before WW I. ${ }^{53}$ The uncertain effect of a tariff reform package on workers living standards takes us a long way to understanding the hesitant opposition to agrarian protectionism of the workers movement on the eve of World War I.

Capital owners in non-food urban industries would be little affected by a dismantling of agricultural and food tariffs. Since there were hardly any backward linkages from these industries to agriculture they would primarily be affected by changes in wages, tax payments and final demand for their products following a tariff reform. For most of these industries the most favourable of our simulations would be an integrated labour market when nominal wages would decline in urban industries ${ }^{54}$, but all in all the reward to capital owners in these industries would only be marginally affected. However, capital owners would benefit from lower consumer prices. Thus, even if their nominal incomes would change only slightly their buying power over consumer goods would increase. Arguably, this was of little concern to urban capitalists since most of their incomes were saved and only a small share was spent on basic food necessities.

Of special interest for the issues in this paper is how capital owners in the food industries would be affected. The reward to capital owners in the animal food industry would increase considerably, since output would increase as a result of enlarged exports and input costs would decline. Their peers in the vegetable food industry would only loose slightly, despite sharply falling sales prices. Apparently, lower nominal wages and input prices compensated for falling output prices.

Bread-grain producers would unequivocally lose a lot from a removal of agrarian tariffs. What would have happened to farmers specializing in animal produce depends on to what extent producers in the bread-grain sector were able to switch over to animal husbandry. In the real world it would obviously take time to convert farms from bread-grain to animal produce and costs would have to be incurred. If we simply disregard such transition costs and assume that farms could be converted from bread-grain to animal production immediately and effortlessly, output of animal products would expand the expense of bread-grain. The reward to landownership would in this case fall by roughly 15 percent (simulation 2 and 3). This figure should be interpreted as what the average landowner would lose from a dismantling of

53 See for example Thomas, Social and Economic Aspects.

54 However, the export industry would benefit more in the case of separate urban and rural labour markets since it was heavily dependent on inputs from the forestry sector which would benefit from declining rural wages. 
agrarian and food tariffs given the opportunity to switch over from bread-grain to animal produce. Small farmers would in general fare better since most of them already specialized in animal husbandry, but in none of the counterfactual scenarios do the factor rewards for animal producers rise. Also, even if small farms heavily specialized in animal produce they also produced some bread-grain. Moreover, small farmers were also dependent on wage income for their livelihood, whether on imputed wages for labour they performed on their own farms or wages for part-time labour on larger estates. The results of the counterfactual simulations underline what can be shown by effective protection rates, namely that small farmers gained from agrarian protectionism, although not to the same extent as large landowners.

The paper illustrates a general theme in the literature on the political economy of tariffs. There was one group that clearly benefited from agrarian protectionism, namely landowners specializing in bread-grain production. The eventual benefit to other groups in society of a dismantling of agrarian protectionism was uncertain and less clear-cut. This also explains why agrarian protectionism, though controversial, showed great persistency once instituted. 
TABLE 1. Import penetration ratio (\%) of the domestic market for grain, 1881/85-1911/13.

\begin{tabular}{lcccc}
\hline \hline & Barley & Oats & Rye & Wheat \\
\hline $1881 / 1885$ & 4 & 0 & 23 & 34 \\
$1886 / 1890$ & 1 & 0 & 20 & 30 \\
$1891 / 1895$ & 2 & 0 & 15 & 49 \\
$1896 / 1900$ & 2 & 2 & 15 & 52 \\
$1901 / 1905$ & 1 & 6 & 16 & 59 \\
$1906 / 1910$ & 1 & 7 & 9 & 52 \\
$1911 / 1913$ & 0 & 7 & 12 & 46 \\
\hline
\end{tabular}

Sources: Lindahl, et al., National Income, Part Two, pp. 30-37, table 66.

Note: The import penetration ratio is calculated as imports /(domestic output - exports + imports).

TABLE 2. Distribution of total arable land in Sweden, 1880-1910 (1000 hectares) among different uses

\begin{tabular}{cccccc}
\hline \hline & Bread-grain 1$)$ & Oats ${ }^{2}$ & Fodder grain & Fallow & $\begin{array}{c}\text { Total Arable } \\
\text { land }\end{array}$ \\
\hline 1880 & 448.5 & 742.2 & 831.0 & 424.2 & 2917.5 \\
1885 & 446.9 & 832.6 & 936.1 & 405.3 & 3079.2 \\
1890 & 460.9 & 906.3 & 1029.4 & 410.6 & 3271.0 \\
1895 & 474.7 & 947.3 & 1106.7 & 420.9 & 3423.7 \\
1900 & 489.0 & 954.6 & 1190.2 & 413.9 & 3519.9 \\
1905 & 493.6 & 963.0 & 1264.4 & 402.0 & 3592.6 \\
1910 & 499.1 & 953.7 & 1349.0 & 362.6 & 3644.9 \\
\hline
\end{tabular}

Source: Höijer, Tabeller, pp. 18-20 table 14a.

Notes: 1) Rye and wheat

2) Oats and dredge (a mixture of oats and rye, which was used for animal fodder).

3) Cultivated crops used for producing hay and for grazing.

TABLE 3. Distribution of farms on various size classes (hectares) and the cultivated acreage per size class, Sweden 1919

\begin{tabular}{lccccccc}
\hline \hline $\begin{array}{c}\text { Size classes of } \\
\text { farms } \\
\text { (hectares) }\end{array}$ & $\begin{array}{c}\text { Number of } \\
\text { farms }\end{array}$ & $\begin{array}{c}\text { Percentage } \\
\text { of total } \\
\text { number of } \\
\text { farms }\end{array}$ & $\begin{array}{c}\text { Cumulative } \\
\text { percentage }\end{array}$ & Hectares & $\begin{array}{c}\text { Percentage } \\
\text { of total } \\
\text { cultivated } \\
\text { acreage }\end{array}$ & $\begin{array}{c}\text { Cumulative } \\
\text { percentage }\end{array}$ & $\begin{array}{c}\text { Average farm } \\
\text { size (hectares) }\end{array}$ \\
\hline $0.26-1$ & 56232 & 13 & 13 & 38147 & 1 & 1 & 0.678 \\
$>1-2$ & 64556 & 15 & 28 & 100990 & 3 & 4 & 1.564 \\
$>2-5$ & 115947 & 27 & 55 & 401493 & 10 & 14 & 3.463 \\
$>5-10$ & 92857 & 50 & 77 & 679914 & 18 & 32 & 7.322 \\
$>10-20$ & 61707 & 14 & 91 & 872102 & 23 & 55 & 14.133 \\
$>20-30$ & 18069 & 4 & 95 & 443165 & 12 & 67 & 24.526 \\
$>30-50$ & 11459 & 3 & 98 & 438709 & 12 & 79 & 38.285 \\
$>50-100$ & 5355 & 1 & 99 & 365820 & 9 & 88 & 68.314 \\
$>100$ & 2576 & 1 & 100 & 441484 & 12 & 100 & 171.384 \\
Sum & 428758 & & & 3781824 & & & 8.820 \\
\hline
\end{tabular}

Source: Höijer, Tabeller, pp. 62-65, table 14. 
TABLE 4. Percentage distribution of output (\%) on farms of different sizes

\begin{tabular}{lcccccccc}
\hline \hline $\begin{array}{c}\text { Size classes } \\
\text { of farms } \\
\text { (hectares) }\end{array}$ & $\begin{array}{c}\text { Bread- } \\
\text { grain 1) }\end{array}$ & $\begin{array}{c}\text { Other } \\
\text { vegetables } \\
\text { 2) }\end{array}$ & $\begin{array}{c}\text { Total } \\
\text { arable } \\
\text { produce }\end{array}$ & $\begin{array}{c}\text { Slaughter } \\
\text { animals } \\
\text { 3) }\end{array}$ & Pigs & Milk & Poultry ${ }^{4)}$ & $\begin{array}{c}\text { Total } \\
\text { animal } \\
\text { produce }\end{array}$ \\
\hline $0-1$ & 4 & 17 & 21 & 11 & 11 & 47 & 10 & 79 \\
$>1-2$ & 6 & 17 & 23 & 12 & 9 & 49 & 7 & 77 \\
$>2-5$ & 8 & 20 & 28 & 14 & 9 & 44 & 5 & 72 \\
$>5-10$ & 11 & 24 & 35 & 14 & 10 & 38 & 4 & 65 \\
$>10-20$ & 16 & 27 & 43 & 12 & 10 & 31 & 3 & 57 \\
$>20-30$ & 23 & 28 & 51 & 11 & 10 & 27 & 2 & 49 \\
$>30-50$ & 26 & 28 & 54 & 10 & 9 & 25 & 2 & 46 \\
$>50-100$ & 27 & 29 & 56 & 10 & 8 & 25 & 1 & 44 \\
$>100$ & 30 & 29 & 59 & 10 & 7 & 24 & 1 & 41 \\
All Farms & 18 & 26 & 43 & 11 & 9 & 33 & 3 & 57 \\
\hline
\end{tabular}

Sources: See Appendix 1.

Notes: ${ }^{1)}$ Barley, wheat, rye and other crops protected by tariffs, i.e. sugar-beets, peas and beans.

2) Oats, dredge (a mixture of rye and oats used for feeding animals) and potatoes. These crops were not protected by tariffs.

3) Horses, cattle, sheep and goats

4) Hens for slaughter, chickens and eggs.

TABLE 5. Distribution of agricultural output (\%) on farms of different sizes

\begin{tabular}{|c|c|c|c|c|c|c|c|c|}
\hline $\begin{array}{c}\text { Size } \\
\text { classes of } \\
\text { farms } \\
\text { (hectares) }\end{array}$ & $\begin{array}{l}\text { Bread- } \\
\text { grain 1) }\end{array}$ & $\begin{array}{c}\text { Other } \\
\text { vegetables } \\
\text { 2) }\end{array}$ & $\begin{array}{c}\text { Total } \\
\text { arable } \\
\text { produce }\end{array}$ & $\begin{array}{l}\text { Slaughter } \\
\text { animals } 3 \text { ) }\end{array}$ & Pigs & Milk & $\begin{array}{l}\text { Poultry } \\
4\end{array}$ & $\begin{array}{c}\text { Total } \\
\text { animal } \\
\text { produce }\end{array}$ \\
\hline $0-1$ & 1 & 2 & 1 & 3 & 3 & 7 & 3 & 3 \\
\hline$>1-2$ & 1 & 3 & 2 & 5 & 4 & 10 & 7 & 6 \\
\hline$>2-5$ & 6 & 11 & 9 & 17 & 13 & 19 & 18 & 17 \\
\hline$>5-10$ & 12 & 18 & 15 & 24 & 20 & 21 & 21 & 22 \\
\hline$>10-20$ & 21 & 23 & 22 & 24 & 25 & 22 & 21 & 22 \\
\hline$>20-30$ & 14 & 12 & 13 & 11 & 11 & 8 & 9 & 9 \\
\hline$>30-50$ & 16 & 11 & 13 & 10 & 10 & 6 & 8 & 8 \\
\hline$>50-100$ & 12 & 9 & 10 & 8 & 7 & 4 & 6 & 6 \\
\hline$>100$ & 17 & 12 & 14 & 9 & 7 & 3 & 7 & 7 \\
\hline $\begin{array}{l}\text { All } \\
\text { Farms }\end{array}$ & 100 & 100 & 100 & 100 & 100 & 100 & 100 & 100 \\
\hline
\end{tabular}

Sources: See Appendix 1.

Notes: See Table 4. 
TABLE 6. Nominal and effective protection for arable products (\%), 1901/05-1911/14

\begin{tabular}{|c|c|c|c|c|c|c|c|}
\hline \multicolumn{8}{|c|}{ Nominal tariffs } \\
\hline & Rye & Wheat & Barley & Oats & Beans/Peas & Sugar beats & Potatoes \\
\hline $1901 / 05$ & 37.0 & 29.0 & 34.0 & 0.0 & 25.0 & 65.0 & 0.0 \\
\hline $1906 / 10$ & 30.0 & 26.0 & 30.0 & 0.0 & 22.0 & 50.0 & 0.0 \\
\hline $1911 / 14$ & 32.0 & 25.0 & 26.0 & 0.0 & 21.0 & 35.0 & 0.0 \\
\hline \multicolumn{8}{|c|}{ Effective tariffs } \\
\hline $1901 / 05$ & 38.0 & 30.9 & 34.9 & -0.1 & 29.3 & 81.6 & -0.5 \\
\hline $1906 / 10$ & 30.7 & 27.4 & 30.7 & -0.1 & 25.9 & 59.4 & -0.5 \\
\hline $1911 / 14$ & 32.7 & 26.3 & 26.5 & -0.1 & 24.2 & 40.1 & -0.5 \\
\hline
\end{tabular}

Sources: See Appendix 1.

TABLE 7. Nominal and effective protection for animal products (\%), 1901/05-1911/14

\begin{tabular}{lccccc}
\hline \hline & \multicolumn{2}{c}{ Nominal tariffs } & & \\
& Live cattle & Milk & Poultry & Eggs & Hogs \\
\hline $1901 / 05$ & 4.0 & 0.0 & 0.0 & 0.0 & 17.0 \\
$1906 / 10$ & 4.0 & 0.0 & 0.0 & 0.0 & 15.0 \\
$1911 / 14$ & 3.0 & 0.0 & 0.0 & 0.0 & 13.0 \\
\hline \multicolumn{7}{c}{ Effective tariffs } & 0.0 & 32.6 \\
\hline $1901 / 05$ & 7.0 & 0.0 & 0.0 & 0.0 & 8.2 \\
$1906 / 10$ & 7.0 & 0.0 & 0.0 & 0.0 & 46.6 \\
$1911 / 14$ & 5.0 & 0.0 & 0.0 & & \multirow{2}{*}{0} \\
\hline
\end{tabular}

Sources: See Appendix 1.

TABLE 8. Average effective protection ( \%), for farms of various sizes 1911/14.

\begin{tabular}{lc}
\hline \hline hectares & Average effective protection $1911 / 14$ \\
\hline $0-$ & 4.4 \\
$>1-2$ & 4.5 \\
$>2-5$ & 5.4 \\
$>5-10$ & 6.7 \\
$>10-20$ & 8.3 \\
$>20-30$ & 10.0 \\
$>30-50$ & 11.0 \\
$>50-100$ & 10.7 \\
$>100$ & 11.2 \\
All Farms & 8.4 \\
\hline
\end{tabular}

Note: The effective protection rate for each size class is a weighted average obtained by multiplying the product specific effective protection rate by its share of total value added in each size class. 
Jan Bohlin: The income distributional consequences of agrarian tariffs on the eve of World War I

TABLE 9. Simulation 1, sector specific capital in all sectors, separate urban and rural labour markets. Percentage changes in output and prices

\begin{tabular}{|c|c|c|c|c|c|c|c|c|c|c|c|c|}
\hline & $\begin{array}{c}\text { Output } \\
\text { volume }\end{array}$ & $\begin{array}{l}\text { Price } \\
\text { Output }\end{array}$ & $\begin{array}{c}\text { Output } \\
\text { nomi- } \\
\text { nal }\end{array}$ & $\begin{array}{l}\text { Import } \\
\text { volume }\end{array}$ & $\begin{array}{c}\text { Price } \\
\text { imports }\end{array}$ & $\begin{array}{c}\text { Import } \\
\text { nomi- } \\
\text { nal }\end{array}$ & $\begin{array}{l}\text { Exports } \\
\text { volume }\end{array}$ & $\begin{array}{c}\text { Price } \\
\text { exports }\end{array}$ & $\begin{array}{c}\text { Exports } \\
\text { nomi- } \\
\text { nal }\end{array}$ & $\begin{array}{l}\text { Reward } \\
\text { to } \\
\text { Capital }\end{array}$ & $\begin{array}{c}\begin{array}{c}\text { Nomi- } \\
\text { nal } \\
\text { wages }\end{array} \\
\end{array}$ & $\begin{array}{c}\text { Real } \\
\text { wages }\end{array}$ \\
\hline EXP_IND & 0.6 & -0.8 & -0.2 & -1.3 & 0.0 & -1.3 & 0.8 & -0.4 & 0.4 & 1.9 & - & - \\
\hline CAP_IND & -0.4 & -0.2 & -0.6 & -0.9 & 0.0 & -0.9 & 0.0 & 0.0 & 0.0 & -1.9 & - & - \\
\hline CONS_IND & -0.6 & -0.2 & -0.7 & -1.5 & 0.0 & -1.5 & 0.0 & 0.0 & 0.0 & -1.9 & - & - \\
\hline FOOD_ANIM & 5.7 & -4.3 & 1.2 & -4.9 & -2.9 & -7.6 & 10.7 & -2.0 & 8.5 & 12.6 & - & - \\
\hline FOOD_VEGE & -0.2 & -13.9 & -14.0 & 75.0 & -23.1 & 34.6 & 37.4 & -6.2 & 28.9 & -1.4 & - & - \\
\hline AGRI_BREAD & -17.3 & -15.2 & -29.9 & 48.1 & -20.0 & 18.4 & 86.4 & -6.0 & 75.2 & -33.9 & - & - \\
\hline AGRI_VEGE & 3.5 & -3.0 & 0.4 & -11.2 & 0.0 & -11.2 & 8.2 & -1.6 & 6.5 & -1.4 & - & - \\
\hline AGRI_ANIM & 3.2 & -4.3 & -1.2 & -8.8 & -2.0 & -10.6 & 11.2 & -2.1 & 8.9 & -2.6 & - & - \\
\hline FORESTRY & 0.8 & -4.0 & -3.2 & -7.3 & 0.0 & -7.3 & 3.8 & -1.9 & 1.9 & -4.4 & - & - \\
\hline CONSTRUCT & 0.0 & 0.2 & 0.1 & - & - & - & - & - & - & -0.6 & - & - \\
\hline SERVICES & 0.4 & 0.1 & 0.5 & - & - & - & - & - & - & -0.1 & - & - \\
\hline PUBLICSERV & 0.0 & 0.1 & 0.1 & - & - & - & - & - & - & -0.9 & - & - \\
\hline Labour, urban & - & - & - & - & - & - & - & - & - & - & -0.6 & 2.8 \\
\hline Labour, rural & - & - & - & - & - & - & - & - & - & - & -7.2 & -3.8 \\
\hline
\end{tabular}

TABLE 10. Simulation 2, sector specific capital in urban sectors, common factor "land" in agrarian sectors, separate urban and rural labour markets. Percentage changes in output and prices

\begin{tabular}{|c|c|c|c|c|c|c|c|c|c|c|c|c|}
\hline & $\begin{array}{l}\text { Output } \\
\text { volume }\end{array}$ & $\begin{array}{c}\text { Price } \\
\text { Output }\end{array}$ & $\begin{array}{c}\text { Output } \\
\text { nomi- } \\
\text { nal }\end{array}$ & $\begin{array}{l}\text { Import } \\
\text { volume }\end{array}$ & $\begin{array}{l}\text { Price } \\
\text { imports }\end{array}$ & $\begin{array}{c}\text { Import } \\
\text { nomi- } \\
\text { nal }\end{array}$ & $\begin{array}{l}\text { Exports } \\
\text { volume }\end{array}$ & $\begin{array}{c}\text { Price } \\
\text { exports }\end{array}$ & $\begin{array}{c}\text { Exports } \\
\text { nomi- } \\
\text { nal }\end{array}$ & $\begin{array}{l}\text { Reward } \\
\text { to } \\
\text { Capital }\end{array}$ & $\begin{array}{c}\text { Nomi- } \\
\text { nal } \\
\text { wages }\end{array}$ & $\begin{array}{c}\text { Real } \\
\text { wages }\end{array}$ \\
\hline EXP_IND & 0.9 & -1.0 & -0.1 & -1.6 & 0.0 & -1.6 & 1.1 & -0.6 & 0.6 & 2.7 & - & \\
\hline CAP_IND & -0.6 & -0.5 & -1.1 & -1.8 & 0.0 & -1.8 & 0.2 & -0.1 & 0.1 & -2.7 & - & - \\
\hline CONS_IND & -0.7 & -0.5 & -1.3 & -3.5 & 0.0 & -3.5 & 1.0 & -0.2 & 0.8 & -2.4 & - & - \\
\hline FOOD_ANIM & 16.5 & -10.1 & 4.8 & -27.2 & -2.9 & -29.3 & 29.4 & -5.0 & 22.9 & 40.0 & - & - \\
\hline FOOD_VEGE & -0.9 & -13.6 & -14.4 & 76.4 & -23.1 & 35.7 & 36.5 & -6.0 & 28.2 & -4.9 & - & - \\
\hline AGRI_BREAD & -38.7 & -9.7 & -44.7 & 104.7 & -20.0 & 63.7 & 26.2 & -2.3 & 23.3 & - & - & - \\
\hline AGRI_VEGE & 10.5 & -9.8 & -0.3 & -34.2 & 0.0 & -34.2 & 30.1 & -5.1 & 23.5 & - & - & - \\
\hline AGRI_ANIM & 9.2 & -10.2 & -2.0 & -30.3 & -2.0 & -31.6 & 30.7 & -5.2 & 23.9 & - & - & - \\
\hline FORESTRY & 1.0 & -4.8 & -3.8 & -8.7 & 0 & -8.7 & 4.7 & -2.3 & 2.3 & -4.1 & - & - \\
\hline CONSTRUCT & 0.0 & 0.1 & 0.0 & - & - & - & - & - & - & -0.6 & - & - \\
\hline SERVICES & 0.6 & -0.3 & 0.3 & - & - & - & - & - & - & -0.2 & - & - \\
\hline PUBLICSERV & 0.0 & 0.0 & 0.0 & - & - & - & - & - & - & -1.0 & - & - \\
\hline Land & - & - & - & - & - & - & - & - & - & 15.9 & - & - \\
\hline Labour, urban & - & - & - & - & - & - & - & - & - & - & -0.5 & 4.0 \\
\hline Labour, rural & - & - & - & - & - & - & - & - & - & - & -10.8 & -6.3 \\
\hline
\end{tabular}


TABLE 11. Simulation 3, sector specific capital in urban sectors, common factor "land" in agrarian sectors, one labor market. Percentage changes in output and prices

\begin{tabular}{|c|c|c|c|c|c|c|c|c|c|c|c|c|}
\hline & $\begin{array}{l}\text { Output } \\
\text { volume }\end{array}$ & $\begin{array}{l}\text { Price } \\
\text { Output }\end{array}$ & $\begin{array}{c}\text { Output } \\
\text { nomi- } \\
\text { nal }\end{array}$ & $\begin{array}{l}\text { Import } \\
\text { volume }\end{array}$ & $\begin{array}{c}\text { Price } \\
\text { imports }\end{array}$ & $\begin{array}{c}\text { Import } \\
\text { nomi- } \\
\text { nal }\end{array}$ & $\begin{array}{l}\text { Exports } \\
\text { volume }\end{array}$ & $\begin{array}{c}\text { Price } \\
\text { exports }\end{array}$ & $\begin{array}{c}\text { Exports } \\
\text { nomi- } \\
\text { nal }\end{array}$ & $\begin{array}{c}\text { Reward } \\
\text { to } \\
\text { Capital }\end{array}$ & $\begin{array}{c}\text { Nomi- } \\
\text { nal } \\
\text { wages }\end{array}$ & $\begin{array}{c}\text { Real } \\
\text { wages }\end{array}$ \\
\hline EXP_IND & 2.0 & -1.3 & 0.7 & -1.1 & 0.0 & -1.1 & 2.3 & -1.1 & 1.1 & 0.9 & - & - \\
\hline CAP_IND & 1.9 & -3.0 & -1.2 & -4.6 & 0.0 & -4.6 & 3.9 & -1.9 & 1.9 & -1.0 & - & - \\
\hline CONS_IND & 2.9 & -2.5 & 0.4 & -9.6 & 0.0 & -9.6 & 8.2 & -1.6 & 6.5 & 1.5 & - & - \\
\hline FOOD_ANIM & 14.8 & -8.9 & 4.6 & -23.0 & -2.9 & -25.3 & 26.9 & -4.6 & 21.0 & 27.4 & - & - \\
\hline FOOD_VEGE & -0.2 & -14.5 & -14.6 & 69.0 & -23.1 & 30.0 & 41.5 & -6.7 & 32.0 & -7.3 & - & - \\
\hline AGRI_BREAD & -44.5 & -8.1 & -49.0 & 122.1 & -20.0 & 77.7 & 14.5 & -1.3 & 12.9 & 一 & - & - \\
\hline AGRI_VEGE & 8.6 & -8.3 & -0.4 & -29.8 & 0.0 & -29.8 & 26.2 & -4.5 & 20.4 & - & - & - \\
\hline AGRI_ANIM & 7.3 & -8.2 & -1.5 & -23.2 & -2.0 & -24.7 & 25.2 & -4.4 & 19.7 & - & - & - \\
\hline FORESTRY & 1.2 & 0.8 & 2.0 & 2.9 & 0.0 & 2.9 & 0.4 & -0.2 & 0.2 & 2.6 & - & - \\
\hline CONSTRUCT & -0.1 & -4.0 & -4.1 & - & - & - & - & - & - & -6.8 & - & - \\
\hline SERVICES & 1.1 & -1.9 & -0.8 & - & - & - & - & - & - & -0.6 & - & - \\
\hline PUBLICSERV & 0.0 & -4.8 & -4.8 & - & - & - & - & - & - & -6.8 & - & - \\
\hline Land & - & - & - & - & - & - & - & - & - & -15.7 & - & - \\
\hline Labour & - & - & - & - & - & - & 一 & - & - & - & -6.3 & -1.4 \\
\hline
\end{tabular}




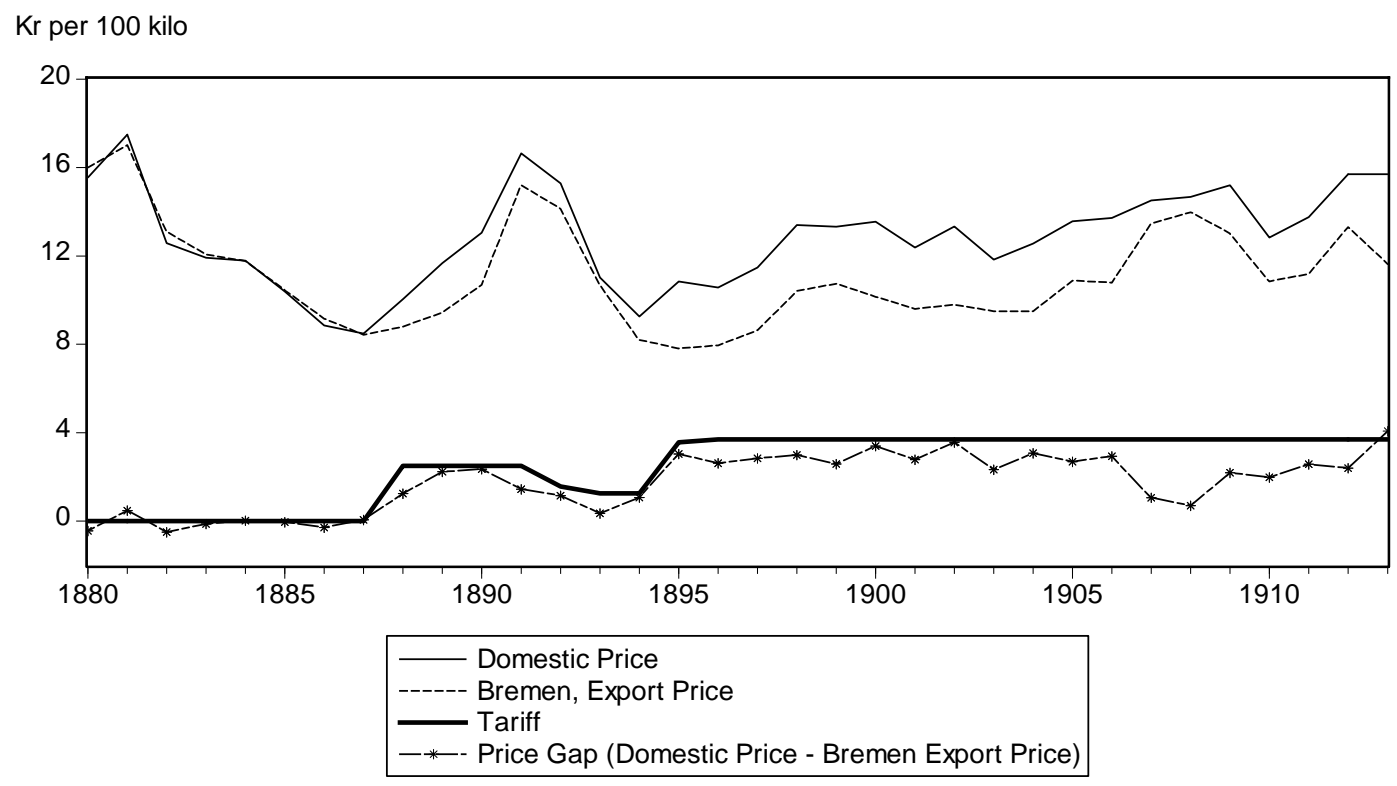

FIGURE 1. Rye, domestic price and Bremen export price

Source: Åmark, Handels- och prisöversikter, pp. 118-26

Note: Prices are yearly averages of monthly prices. Domestic prices are averages of prices in Stockholm and Malmö. 


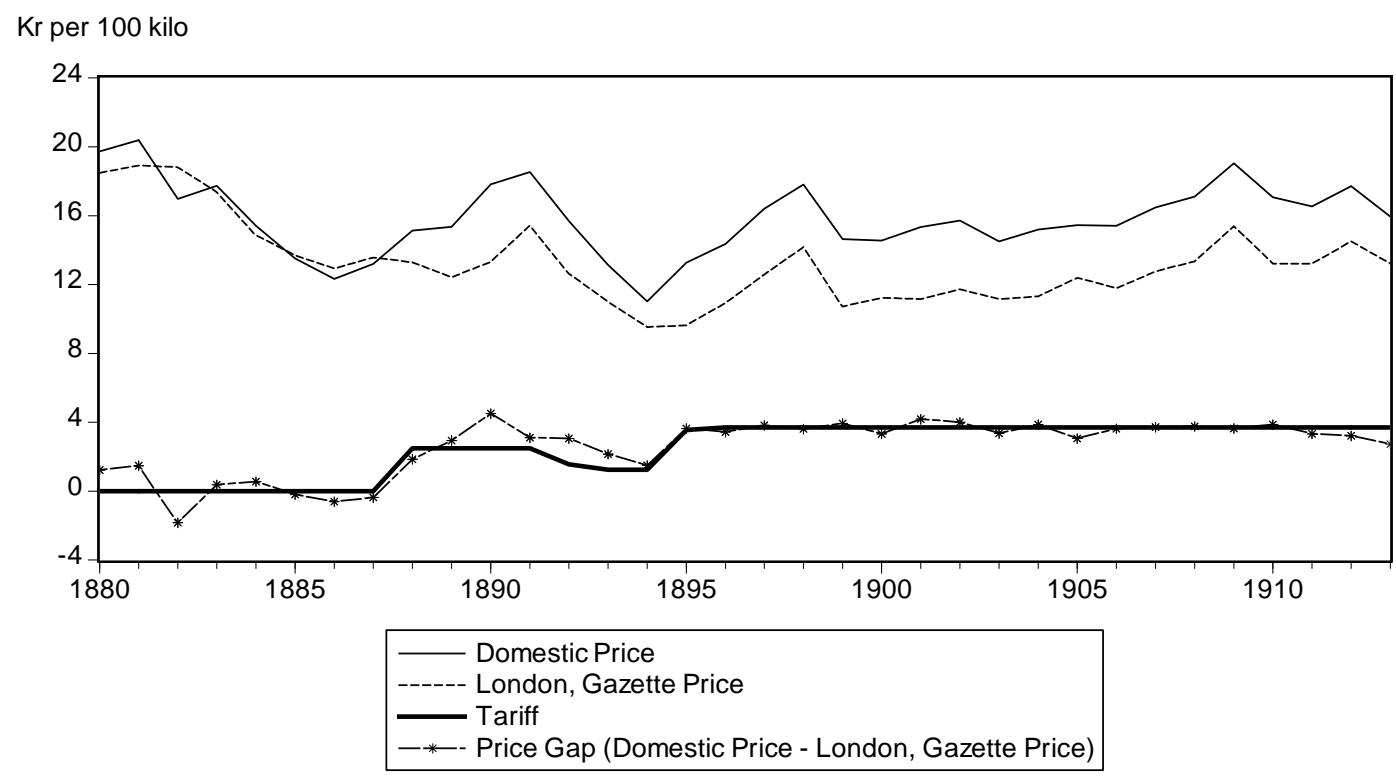

FIGURE 2. Wheat, domestic price and London, Gazette price Source: See Figure 1.

Note: See Figure 1. 


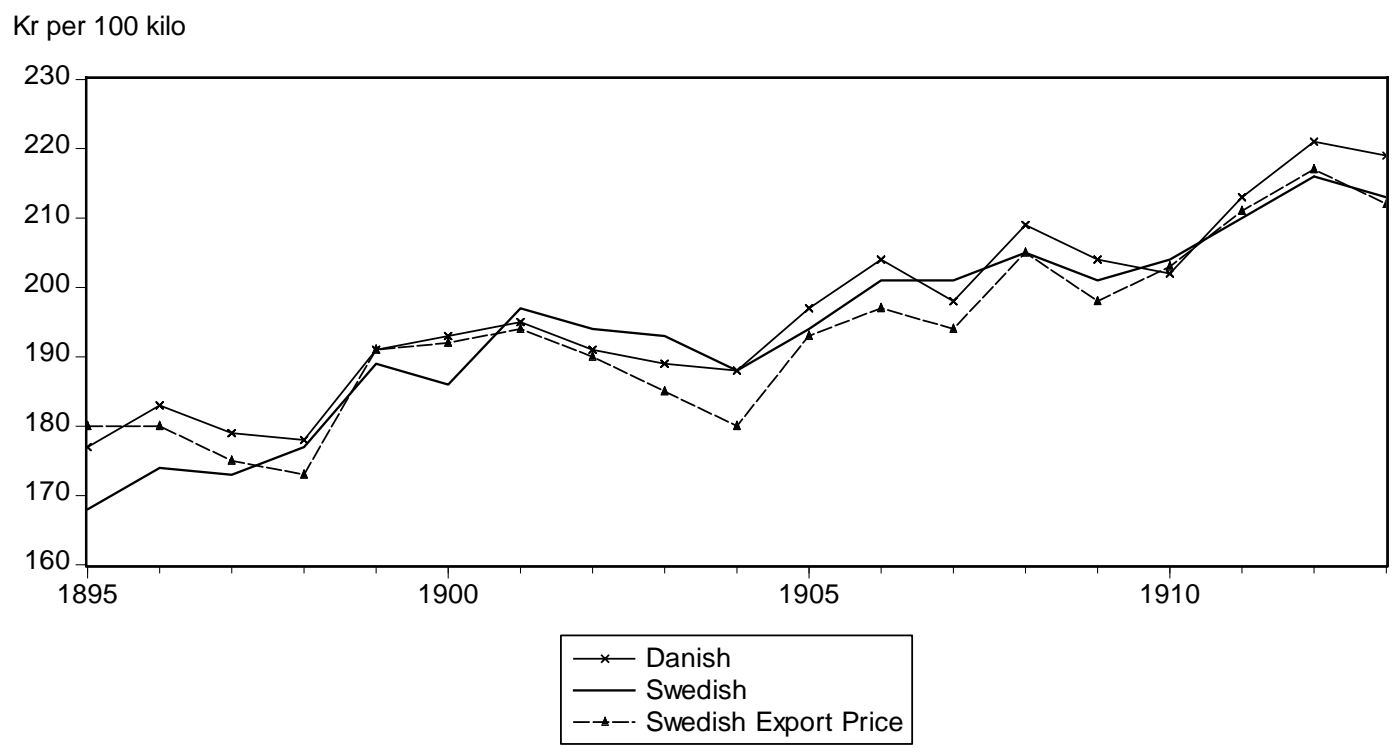

FIGURE 3. Swedish and Danish butter prices, 1895-1913

Source: Danish butter prices Pedersen and Petersen, Analysis of Price Behaviour, pp. 246-47, Swedish home market prices Ljungberg, Priser och marknadskrafter, pp. 386-388, Swedish export prices, Bidrag till Sveriges Officiella Statistik. 
Mill. Kr

1910/12 Prices

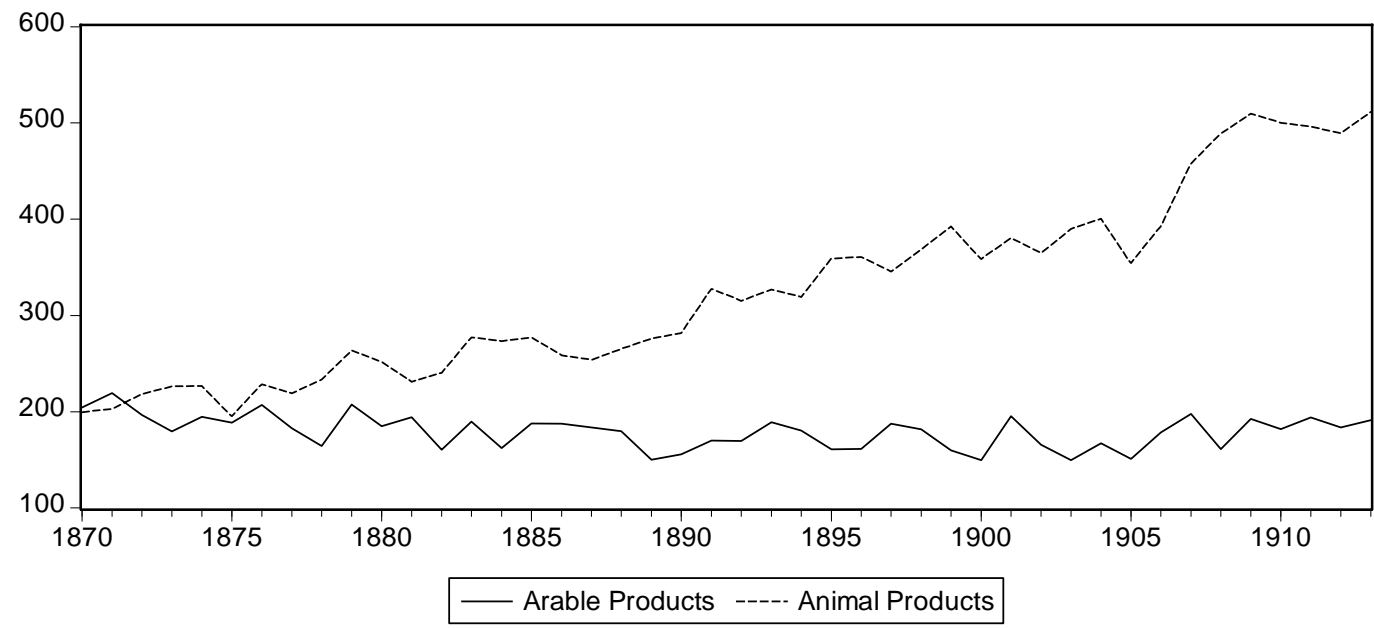

FIGURE 4. Volume of animal and arable produce in Swedish agriculture 1870-1913

Source: Unpublished data provided by Lennart Schön.

Note: It should be noted that the volumes include only products for sales outside of the agricultural sector. For example, grains produced for seeds or animal fodder is not included in the volume of arable produce, and milk used for feeding animals is not included in the volume of animal produce.

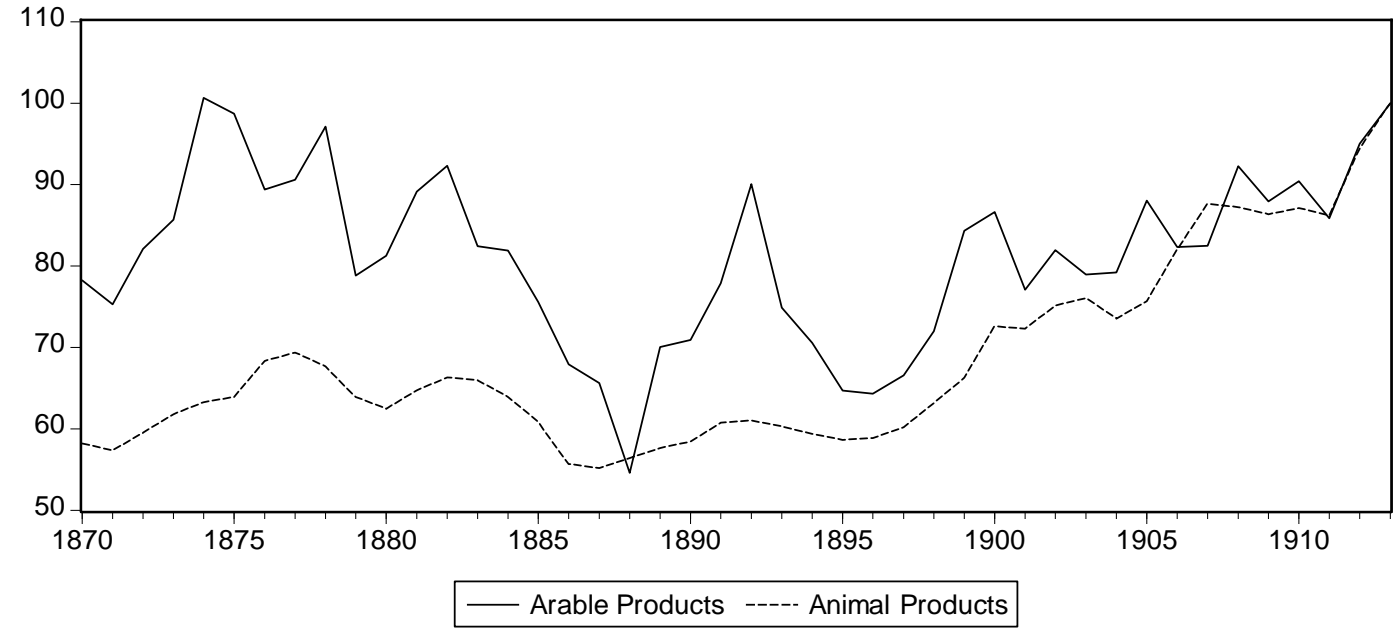

FIGURE 5. Prices for animal products and arable products $(1913=100)$

Source: Animal products and arable products, implicit price indices calculated from unpublished data provided by Lennart Schön. 


\section{Appendix 1. Sources and methods used for calculating farm output, labour use and effective protection rates at farms in different size classes}

\section{Farm output}

For the year 1919 we have data on the number of farms and hectares cultivated by farmers in the following size classes: $0-0.25$ hectares, $>0.25-2$ hectares, $>2-5$ hectares, $>5-10$ hectares, $>10-20$ hectares, $>20-30$ hectares, $>30-50$ hectares, $>50-100$ hectares, $>100$ hectares. ${ }^{55}$. From the same source we also have information for the different size classes of farms on how large a share of the acreage that was used for fallow and for the growing of various crops. In addition, there is data for the same size classes of farms on output (harvest and seed) for wheat, rye, barley, oats, peas and beans. ${ }^{56}$ For other crops I have assumed that the output and seeds for each crop on each farm were the same per hectare as the national average. In order to calculate output for the various crops per classes of farm size I have assumed that their shares of output in 1913 as given in Swedish historical national accounts ${ }^{57}$ were the same as in 1919.

From Historical National Income statistics we have estimates for each year on the number of animals (horses, bullocks, bulls, cows, young cattle and calves, sheep, goats, pigs and poultry). ${ }^{58}$ To estimate the number of animals for different farm sizes in 1913 I have assumed that the size distribution for the various animals was the same as in 1919. For the latter year we have information for each size-class of farms on the number of horses, cows, young cattle and calves, bullocks, bulls, pigs, goats, sheep and lambs. ${ }^{59}$ For poultry we lack information on the size distribution of the number of animals. Poultry was more common among small farmers. To make an educated guess on the distribution of hens among farms of different sizes, I have used information ${ }^{60}$ which gives data on the number of hens per size class in 27 counties in southern and middle Sweden for the year 1917. To estimate the output of animal food products on the various farms sizes in 1913 I have simply assumed that their output per animal of meat, milk, eggs and so on was the same as the national average according to historical national accounts. ${ }^{61}$

\section{Labor use}

To calculate the labour input in the various parts of arable and animal husbandry I have used estimates of normal labour use in different agricultural activities provided by Ludvig Nanneson. ${ }^{62}$ Accordingly, it is

\footnotetext{
${ }^{55}$ Höijer, Undersökning, table $17 \mathrm{a}$.

${ }^{56}$ Höijer, Utredning, pp. 54-74, table 51.

${ }^{57}$ Lindahl, Dahlgren, and Kock, National Income, Part Two, pp. 30-48, table 66.

${ }^{58}$ Ibid., pp. 92-98, table 69.

${ }^{59}$ Höijer, Tabeller, pp. 102, table 123 a-b.

${ }^{60}$ Höijer, Undersökning, pp. table 1-2.

${ }^{61}$ Lindahl, Dahlgren, and Kock, National Income, Part Two, pp. 92-98, table 69, 111, table 173b, 117, table 174, 130131, table 175.

${ }^{62}$ See Nanneson, "Kontroll". For poultry farming I have made an educated guess on the basis of SOU1931:7, Betänkande that labour costs were 27.5 percent of gross output.
} 
assumed that the work hours per hectare and animal in each line of production were the same for each farm size. To calculate labour costs the estimated work hours have been multiplied by $0.25 \mathrm{kr} .{ }^{63}$

\section{Calculations of effective protection rates}

In order to calculate effective tariffs we need data on nominal tariffs ${ }^{64}$ and cost shares for inputs. I have assumed that the only purchased input besides labour in arable production is fertilizer. I have made an educated guess on the cost shares of fertilizer from material presented by Nanneson. ${ }^{65}$ It is assumed that the use of fertilizer per hectare and crop was the same in each size class of farms.

The only purchased input in animal production is concentrated fodder. Based on data given by Nanneson ${ }^{66}$ I assume that the cost share of concentrated fodder in the sales value of live cattle was 40 percent in 1911/14. For hogs production I have assumed that the cost share of purchased inputs in the sales value of hogs was 70 percent in 1911/14 and that maize accounted for 85 percent of these inputs.

I have assumed that fertilizer was the only purchased input in the production of grain and other vegetables. ${ }^{67}$

Assuming the same physical input-output relationships for other years the cost shares of purchased inputs for 1901/05 and 1906/10 have been calculated on the basis of price data given by Jonas Ljungberg and Swedish foreign trade statistics. ${ }^{68}$

63 A weighted average of daily wages for farm workers given by Jörberg, History of Prices,I, pp. 601-603 for various counties (daily wages per county weighted by the countryside population in these counties in 1910 according to the population census) was $2.60 \mathrm{kr}$ in 1913. If we assume 10.3 hours per day of work we arrive at an hourly wage of $0.25 \mathrm{kr}$.

64 See Bohlin, "Tariff protection" and Bidrag till Sveriges Officiella Statistik.

65 Nanneson, "Räkenskapsresultat", pp. 30-33, 62-66.

66 Ibid., pp. 57-62.

${ }^{67}$ For the cost shares of fertilizer for various crops in 1911/14, see ibid., pp. 62-65.

68 Ljungberg, Priser och marknadskrafter, Bidrag till Sveriges Officiella Statistik. 


\section{Appendix 2: Benchmark data for CGE model}

APPENDIX 2 TABLE 1. Final demand and supply, $1913 \mathrm{~m} \mathrm{kr}$

\begin{tabular}{|c|c|c|c|c|c|c|}
\hline & \multicolumn{4}{|c|}{ Final Demand } & \multicolumn{2}{|c|}{ Supply } \\
\hline & $\begin{array}{c}\text { Private } \\
\text { consumption } \\
\text { (excl. of trade } \\
\text { margins) }\end{array}$ & $\begin{array}{c}\text { Public } \\
\text { consumption }\end{array}$ & Investments & Exports & $\begin{array}{l}\text { Imports (incl. of } \\
\text { tariffs) }\end{array}$ & Gross output \\
\hline EXP_IND & 7.645 & & 0.000 & 364.000 & 33.545 & 569.800 \\
\hline CAP_IND & 241.459 & & 153.000 & 186.500 & 194.009 & 945.000 \\
\hline CONS_IND & 511.011 & & 0.000 & 37.600 & 156.511 & 572.600 \\
\hline FOOD_VEGE & 506.826 & & 0.000 & 5.100 & 40.110 & 601.400 \\
\hline FOOD_ANIM & 92.206 & & 0.000 & 71.800 & 9.006 & 168.600 \\
\hline CONSTRUCT & 0.000 & & 321.900 & 0.000 & 0.000 & 452.000 \\
\hline SERVICES & 1217.100 & & 0.000 & 225.700 & 0.000 & 1767.000 \\
\hline PUBLICSERV & & 264.000 & 0.000 & 0.000 & 0.000 & 264.000 \\
\hline FORESTRY & 66.569 & & 0.000 & 21.000 & 1.069 & 276.000 \\
\hline AGRI_BREAD & 50.000 & & 0.000 & 0.300 & 79.100 & 195.900 \\
\hline AGRIV_VEGE & 35.000 & & 0.000 & 7.000 & 14.300 & 235.200 \\
\hline AGRI_ANIM & 386.400 & & 0.000 & 21.700 & 6.600 & 555.500 \\
\hline RAWMAT & 12.200 & & 0.000 & 0.000 & 246.800 & \\
\hline NC_AGRIC & 30.500 & & 0.000 & 0.000 & 133.100 & \\
\hline
\end{tabular}

Sources: See Appendix table 5

APPENDIX 2 TABLE 2. Factor payments and capital stock (1913 m kr). Employment (1000s)

\begin{tabular}{|c|c|c|c|c|c|c|c|}
\hline & $\begin{array}{l}\text { Wage sum. } \\
\text { Urban } \\
\text { employees } \\
\text { (incl. of } \\
\text { income taxes) } \\
\text { m. kr }\end{array}$ & $\begin{array}{l}\text { Wage sum. } \\
\text { Rural } \\
\text { employees } \\
\text { (incl. of } \\
\text { income taxes) } \\
\text { m. kr }\end{array}$ & $\begin{array}{l}\text { Surplus (incl. } \\
\text { of income } \\
\text { taxes) } \mathrm{m} . \mathrm{kr}\end{array}$ & $\begin{array}{l}\text { Value added. } \\
\text { m. kr. }\end{array}$ & $\begin{array}{l}\text { Urban } \\
\text { employm. } \\
\text { (1000s) }\end{array}$ & $\begin{array}{c}\text { Rural } \\
\text { employm. } \\
\text { (1000s) }\end{array}$ & $\begin{array}{l}\text { Capital } \\
\text { m. kr. }\end{array}$ \\
\hline EXP_IND & 127.4013 & & 116.1587 & 243.56 & 119.1 & & 359.2 \\
\hline CAP_IND & 278.287 & & 156.253 & 434.54 & 211.4 & & 501.2 \\
\hline CONS_IND & 173.9153 & & 69.0347 & 242.95 & 191.6 & & 255.4 \\
\hline FOOD_VEGE & 51.3898 & & 106.5262 & 157.916 & 51.7 & & 209.9 \\
\hline FOOD_ANIM & 13.1456 & & 1.4544 & 14.6 & 12.8 & & 23.3 \\
\hline FORESTRY & & 69.904 & 78.799 & 254.8 & & 100 & 49 \\
\hline AGRI_BREAD & & 86.7497 & 67.6503 & 86.7497 & & 128.9 & 892.9 \\
\hline AGRI_VEGE & & 104.1804 & 80.2196 & 104.1804 & & 154.8 & 1380.8 \\
\hline AGRI_ANIM & & 194.5643 & 101.9357 & 194.5643 & & 289.1 & 1875.8 \\
\hline CONSTRUCT & 200.655 & & 46.345 & 250.2 & 193.846 & & 10.5 \\
\hline SERVICES & 411.343 & 142.769 & 960.688 & 1514.8 & 370.83 & 268.7 & 3715 \\
\hline PUBLICSERV & 175.011 & 0 & 1.899 & 176.9 & 110.154 & & 578 \\
\hline
\end{tabular}

Sources: See Appendix table 5. 
Göteborg Papers in Economic History no. 6

APPENDIX 2 TABLE 3. Consumption data for formulation of Stone-Geary utility function, $\mathrm{m}$. $\mathrm{kr}$

\begin{tabular}{lccc}
\hline \hline & Baseline consumption & Total private consumption (incl. of trade margins) & Implied income elasticity of demand \\
\hline EXP_IND & 5.000 & 9.997 & 0.66 \\
CAP_IND & 7.200 & 315.733 & 1.28 \\
CONS_IND & 63.000 & 668.201 & 1.19 \\
FOOD_VEGE & 370.000 & 662.729 & 0.58 \\
FOOD_ANIM & 25.000 & 120.569 & 1.04 \\
CONSTRUCT & 0.500 & 0.500 & 0.00 \\
SERVICES & 10.000 & 620.400 & 1.29 \\
FORESTRY & 63.700 & 87.046 & 0.35 \\
AGRI_BREAD & 43.000 & 65.380 & 0.45 \\
AGRI_VEGE & 30.200 & 45.766 & 0.45 \\
AGRI_ANIM & 120.000 & 505.259 & 1.00 \\
RAWMAT & 3.800 & 15.953 & 1.00 \\
NC_AGRIC & 9.400 & 39.882 & 1.00 \\
\hline
\end{tabular}

APPENDIX 2 TABLE 4. Elasticities used in counterfactual simulations

\begin{tabular}{cccc}
$\begin{array}{c}\text { CES, elasticity of } \\
\text { substitution }\end{array}$ & $\begin{array}{c}\text { Armington elasticity } \\
\text { of substitution }\end{array}$ & $\begin{array}{c}\text { CET, elasticity of } \\
\text { transformation }\end{array}$ & $\begin{array}{c}\text { Export demand } \\
\text { elasticity }\end{array}$ \\
\hline 0.5 & 2 & 2 & 2 \\
0.5 & 2 & 2 & 2 \\
0.5 & 5 & 5 & 5 \\
0.5 & 5 & 5 & 5 \\
0.5 & 5 & 5 & 5 \\
0.5 & - & - & - \\
0.5 & - & 2 & 2 \\
1 & 2 & 10 & 10 \\
1 & 10 & 5 & 5 \\
1 & 5 & 5 & 5 \\
1 & 5 & &
\end{tabular}




\begin{tabular}{lc} 
& Tariff \\
\hline \hline & 0 \\
\hline EXP_IND & 10 \\
CAP_IND & 15 \\
CONS_IND & 30 \\
FOOD_VEGE & 3 \\
FOOD_ANIM & 25 \\
AGRI_BREAD & 0 \\
AGRI_VEGE & 3 \\
AGRI_ANIM & 0 \\
FORESTRY & 0 \\
CONSTRUCT & 0 \\
SERVICES & 0 \\
PUBLICSERV & 0 \\
RAWMAT & 20 \\
NC_AGRIC & \\
\hline
\end{tabular}

Income taxes

An income tax of 4.7 percent is levied on the income of all factors

Sales tax

A sales tax of 5 percent is levied on the output of the FOOD_VEGE sector.

Domestic savings

The difference between post-tax factor incomes, after deduction of depreciation on fixed capital ${ }^{69}$, and the value of total private consumption is saved. Accordingly, the savings rate of the representative consumer is computed as (Factor incomes - income taxes - depreciations - total private consumption)/ (Factor incomes - income taxes - depreciations). In the benchmark it is 9.2 percent. This savings rate is applied in all counterfactual simulations. Private savings and depreciations are transferred to "the Investor".

Foreign savings

Apart from depreciations and private savings the Investor also receives or transfers foreign exchange to the outside world. Debt service on foreign debt contracted in earlier periods is $78.8 \mathrm{~m} \mathrm{kr}$. There is also an inflow of emigrant remittances amounting to $36 \mathrm{~m} \mathrm{kr}$. The difference between imports (exclusive of tariffs) and exports is filled by foreign savings. Hence foreign savings in the benchmark is: Imports exports - emigrant remittances + interest payment on foreign debt. In the counterfactual simulations foreign savings adapt to ensure that total investments = total savings.

69 The following depreciation rates on sector specific capital stocks are assumed: EXP_IND 0.03236, CAP_IND 0.03183, CONS_IND 0.0356, FOOD_ANIM 0.03462, FOOD_VEGE 0.0346, 0.0346, CONSTRUCT 0.05, SERVICES 0.0249, PUBLICSERV 0.02507, FORESTRY 0.05, AGRI_BREAD 0.01, AGRI_VEGE 0.01, AGRI_ANIM 0.0286. 
APPENDIX TABLE 6. Input-output table of the Swedish economy 1913, m kr

\begin{tabular}{|c|c|c|c|c|c|c|c|c|c|c|c|c|}
\hline & EXP_IND & CAP_IND & CONS_IND & FOOD_VEGE & FOOD_ANIM & CONSTRUCT & SERVICES & PUBLICSERV & FORESTRY & AGRI_BREAD & AGRI_VEGE & AGRI_ANIM \\
\hline EXP_IND & 77.600 & 37.300 & 16.900 & 3.100 & 0.300 & 62.000 & 20.500 & 10.000 & 0.000 & 1.000 & 2.000 & 1.000 \\
\hline CAP_IND & 14.690 & 352.760 & 16.000 & 3.100 & 0.200 & 82.000 & 29.000 & 19.000 & 4.000 & 14.200 & 22.100 & 1.000 \\
\hline CONS_IND & 0.000 & 2.700 & 136.500 & 6.800 & 0.000 & 7.000 & 7.500 & 19.000 & 0.000 & 1.000 & 0.000 & 0.000 \\
\hline FOOD_VEGE & 0.000 & 0.000 & 1.000 & 124.584 & 0.000 & 0.000 & 0.000 & 0.000 & 0.000 & 0.000 & 0.000 & 4.000 \\
\hline FOOD_ANIM & 0.000 & 0.000 & 13.100 & 0.500 & 0.000 & 0.000 & 0.000 & 0.000 & 0.000 & 0.000 & 0.000 & 0.000 \\
\hline CONSTRUCT & 1.900 & 1.200 & 3.600 & 1.900 & 0.500 & 0.000 & 63.000 & 27.000 & 0.000 & 7.300 & 14.700 & 9.000 \\
\hline SERVICES & 32.500 & 39.500 & 22.900 & 25.300 & 5.600 & 54.000 & 93.100 & 7.100 & 17.200 & 8.000 & 12.000 & 7.000 \\
\hline PUBLICSERV & 0.000 & 0.000 & 0.000 & 0.000 & 0.000 & 0.000 & 0.000 & 0.000 & 0.000 & 0.000 & 0.000 & 0.000 \\
\hline FORESTRY & 179.750 & 4.800 & 4.950 & 0.000 & 0.000 & 0.000 & 0.000 & 0.000 & 0.000 & 0.000 & 0.000 & 0.000 \\
\hline AGRI_BREAD & 0.000 & 0.000 & 0.000 & 202.600 & 0.000 & 0.000 & 0.000 & 0.000 & 0.000 & 0.000 & 0.000 & 22.100 \\
\hline AGRI_VEGE & 0.000 & 0.000 & 0.000 & 22.100 & 0.000 & 0.000 & 0.000 & 0.000 & 0.000 & 0.000 & 0.000 & 185.400 \\
\hline AGRI_ANIM & 0.000 & 0.000 & 7.000 & 0.000 & 147.000 & 0.000 & 0.000 & 0.000 & 0.000 & 0.000 & 0.000 & 0.000 \\
\hline RAWMAT & 19.800 & 72.200 & 93.200 & 4.900 & 0.400 & 0.000 & 39.100 & 5.000 & 0.000 & 0.000 & 0.000 & 0.000 \\
\hline NC_AGRIC & 0.000 & 0.000 & 14.500 & 48.600 & 0.000 & 0.000 & 0.000 & 0.000 & 0.000 & 10.000 & 0.000 & 29.500 \\
\hline
\end{tabular}




\section{References}

Adelman, Irma, and Sherman Robinson. Income Distribution Policy in Developing Countries. A Case Study of Korea. Oxford: Oxford University Press, 1978.

Bidrag till Sveriges Officiella Statistik, serie F Handel.

Bohlin, Jan. "Tariff Protection in Sweden, 1885-1914." Scandinavian Economic History Review, no. 2 (2005): 7-29.

Corden, Werner Max. The Theory of Protection. Oxford: Clarendon Press, 1971.

Federico, Giovanni, and Kevin O'Rourke. "Much Ado About Nothing? Italian Trade Policy in the Late Nineteenth Century." In The Mediterranean Response to Globalization Before 1950, edited by Sevket Pamuk and Jeffrey Williamson, 269-96. London: Routledge, 2000.

Gellerman, Olle. Staten och jordbruket 1867-1918. Stockholm: Almquist \& Wicksell, 1958.

Gerschenkron, Alexander. Bread and Democracy in Germany. Berkeley: University of California Press, 1943.

Gårestad. Industrialisering och beskattning i Sverige 1861-1914. Uppsala: Uppsala Studies in Economic History, 1987.

Heathfield, David F., and Sören Wibe. An Introduction to Cost and Production Functions. London: MacMillan, 1987.

Henriksen, Ingrid, and Kevin H. O'Rourke. "Incentives, Technology and the Shift to Year-Round Dairying in Late Nineteenth century Denmark." Economic History Review LVIII, no. 3 (2005): 520-54.

Holgersson, Bengt. "Cultivated Land in Sweden and its Growth 1840-1939." Economy and History XXII (1974): $20-51$.

Höijer, Ernst. Jämförelse mellan jordbrukets utveckling i vissa delar av Sverige samt Danmark och Norge, Tull- och traktatkommtténs utredningar och betänkanden IV. Stockholm: SOU, 1921.

- Tabeller till belysning av det svenska jordbrukets utveckling 1871-1919 jämte anmärkningar, Tull- och traktatkommitténs betänkanden V. Stockholm: SOU, 1921.

—. Undersökning av det större och mindre jordbrukets produktion. Stockholm, 1919.

—. Utredning angående det svenska jordbrukets produktion samt saluöverskott av spannmål, Tull- och traktatkommtténs utredningar och betänkanden III. Stockholm: SOU, 1921.

Irwin, Douglas A. "Could the United States Iron Industry have Survived Free Trade After the Civil War?" Explorations in Economic History 37, no. 3 (2000): 278-99.

Johansen, Leif. A Multi-Sectoral Study of Economic Growth. Second enlarged edition ed. Amsterdam, Oxford: North-Holland publishing company, 1974.

Jungenfelt, Karl G. Löneandelen och den ekonomiska utvecklingen. En empirisk-teoretisk studie. Uppsala: Almqvist \& Wicksell, 1966.

Jörberg, Lennart. A History of Prices in Sweden 1732-1914. Volume I Sources, Methods Tables. Lund: Gleerup, 1972.

-. A History of Prices in Sweden 1732-1914. Volume II Description, Analysis. Lund: Gleerup, 1972.

Karlström, Urban. Economic Growth and Migration during the Industrialization of Sweden. Stockholm: EFI, 1985.

Krantz, Olle. Historiska nationalräkenskaper för Sverige: Privata tjänster och bostadutnyttjande 1800-1980. Lund: Ekonomisk-historiska föreningen, 1991.

Lindahl, Erik, Einar Dahlgren, and Karin Kock. National Income of Sweden 1861-1930. Part Two. Stockholm: Norstedt, 1937.

Ljungberg, Jonas. Priser och marknadskrafter i Sverige 1885-1969. En prishistorisk studie. Lund: Ekonomiskhistoriska föreningen i Lund, 1990.

Nanneson, Ludvig. "Kontroll över jordbrukets arbetsförbrukning." Landtmannen (1922).

. "Räkenskapsresultat från svenska jordbruk i bokföringsåret 1914-1915." Meddelanden från Kungliga Lantbruksstyrelsen, no. 201 (1916).

O’Rourke, K. H. "The European Grain Invasion, 1870-1913." Journal of Economic History 57, no. 4 (1997): 775-801. 
O’Rourke, Kevin H., and Jeffrey G. Williamson. "Open Economy Forces and Late Nineteenth Century Swedish Catch-Up. A Quantitative Accounting." Scandinavian Economic History Review XLIII, no. 2 (1995): 171-203.

Pedersen, Jörgen, and O. Strange Petersen. An Analysis of Price Behaviour Dduring the Period 1855--1913. Copenhagen and London: Levin\&Munkgsgaard, Humphrey Milford, 1938.

Schön, Lennart. Historiska nationalräkenskaper for Sverige: Industri och hantverk. Lund: Ekonomisk-historiska föreningen, 1988.

—. "Kapitalimport, kreditmarknad och industrialisering 1850-1910." In Upplaning och utveckling. Riksgäldskontoret 1789-1989, edited by Erik Dahmén, 227-308. Stockholm: Riksgäldskontoret, 1989.

SOU 1931:7, Betänkande angående àtgärder för fjäderfäskötselns främjande, Stockholm: 1931.

Staffansson, Jan-Åke. Svenskt smör. Produktion, konsumtion och utrikeshandel 1861-1913. Lund: Lund University Press, 1995.

Stone, Richard. "Linear expenditure systems and demand analysis: an application to the pattern of British demand." Economic Journal 64, no. 255 (1954): 511-27.

Thomas, Dorothy Swain. Social and Economic Aspects of Swedish Population Movements 1750-1933. New York: MacMillan, 1941.

Webb, Steven B. "Agricultural Protection in Wilhelminian Germany: Forging an Empire with Pork and Rye." Journal of Economic History XLII, no. 2 (1982): 309-26.

Vikström, P. The Big Picture. A Historical National Accounts Approach to Growth, Structural Change and Income Distribution in Sweden 1870--1990. Umeå: Department of Economic History, 2000.

Åmark, Karl. Handels- och prisöversikter rörande spannmål. Jämte bihang innefattande vissa internationella prisjämförelser angående viktiga jordbruksprodukter, Tull- och traktatkommtténs utredningar och betänkanden XXV. Stockholm: SOU:1924:55, 1924. 


\title{
Göteborg Papers in Economic History
}

\author{
Available online at S-WOPEC: (http://swopec.hhs.se/gunhis/)
}

1. Jan Bohlin: Tariff protection in Sweden 1885-1914. 2005.

2. Svante Larsson: Globalisation, inequality and Swedish catch up in the late nineteenth century. Williamson's real wage comparisons under scrutiny. 2005

3. Staffan Granér: Thy Neighbours Property. Communal property rights and institutional change in an iron producing forest district of Sweden 1630-1750. 2005

4. Klas Rönnbäck: Flexibility and protectionism. Swedish trade in sugar during the early modern era. 2006.

5. Oskar Broberg: Verkstadsindustri i globaliseringens tidevarv. En studie av SKF och Volvo 1970-2000. 2006.

6. Jan Bohlin: The income distributional consequences of agrarian tariffs in Sweden on the eve of World War I. 2006. 